\title{
An airborne infrared laser spectrometer for in-situ trace gas measurements: application to tropical convection case studies
}

V. Catoire ${ }^{1}$, G. Krysztofiak ${ }^{1}$, C. Robert ${ }^{1}$, M. Chartier $^{1}$, P. Jacquet ${ }^{1}$, C. Guimbaud ${ }^{1}$, P. D. Hamer ${ }^{2,3}$, and V. Marécal ${ }^{3}$

${ }^{1}$ LPC2E, Université Orléans - CNRS (UMR 7328), 3A Avenue de la Recherche Scientifique, 45071 Orléans CEDEX 2, France

${ }^{2}$ CNRM-GAME, Météo-France - CNRS (UMR 3589), 42 Avenue G. Coriolis, 31057 Toulouse CEDEX 1, France

${ }^{3}$ NILU, P.O. Box 100, 2027 Kjeller, Norway

Received: 28 July 2015 - Accepted: 13 August 2015 - Published: 7 September 2015

Correspondence to: V. Catoire (valery.catoire@cnrs-orleans.fr)

Published by Copernicus Publications on behalf of the European Geosciences Union.

An airborne infrared laser spectrometer for in-situ trace gas measurements

V. Catoire et al.

\section{Title Page}

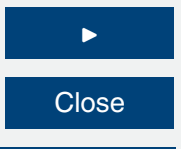

Full Screen / Esc

Printer-friendly Version

Interactive Discussion 


\section{Abstract}

A three-channel laser absorption spectrometer called SPIRIT (SPectromètre InfraRouge In situ Toute altitude) has been developed for airborne measurements of trace gases in the troposphere and lower stratosphere. More than three different species 5 can be measured simultaneously with high time resolution (each $1.6 \mathrm{~s}$ ) using three individual CW-DFB-QCLs (Continuous Wave Distributed FeedBack Quantum Cascade Lasers) coupled to a single Robert multipass optical cell. The lasers are operated in a time-multiplexed mode. Absorption of the mid-infrared radiations occur in the cell (2.8 L with effective path lengths of 134 to $151 \mathrm{~m}$ ) at reduced pressure, with detection 10 achieved using a HgCdTe detector cooled by Stirling cycle. The performances of the instrument are described, in particular precisions of 1,1 and $3 \%$, and volume mixing ratio (vmr) sensitivities of $0.4,6$ and $2.4 \mathrm{ppbv}$ are determined at $1.6 \mathrm{~s}$ for $\mathrm{CO}, \mathrm{CH}_{4}$ and $\mathrm{N}_{2} \mathrm{O}$, respectively (at $1 \sigma$ confidence level). Estimated accuracies without calibration are about $6 \%$. Dynamic measuring ranges of about four decades are established. The first deployment of SPIRIT was realized aboard the Falcon-20 research aircraft operated by DLR (Deutsches Zentrum für Luft- und Raumfahrt) within the frame of the SHIVA (Stratospheric Ozone: Halogen Impacts in a Varying Atmosphere) European project in November-December 2011 over Malaysia. The convective outflows from two large convective systems near Borneo Island $\left(6.0^{\circ} \mathrm{N}-115.5^{\circ} \mathrm{E}\right.$ and $\left.5.5^{\circ} \mathrm{N}-118.5^{\circ} \mathrm{E}\right)$ were sampled above $11 \mathrm{~km}$ in altitude on 19 November and 9 December, respectively. Correlated enhancements in $\mathrm{CO}$ and $\mathrm{CH}_{4}$ vmr were detected when the aircraft crossed the outflow anvil of both systems. These enhancements were interpreted as the fingerprint of transport from the boundary layer up through the convective system and then horizontal advection in the outflow. Using these observations, the fraction of boundary 25 layer air contained in fresh convective outflow was calculated to range between 22 and $31 \%$, showing the variability of the mixing taking place during convective transport.

\section{AMTD}

8, 9165-9207, 2015

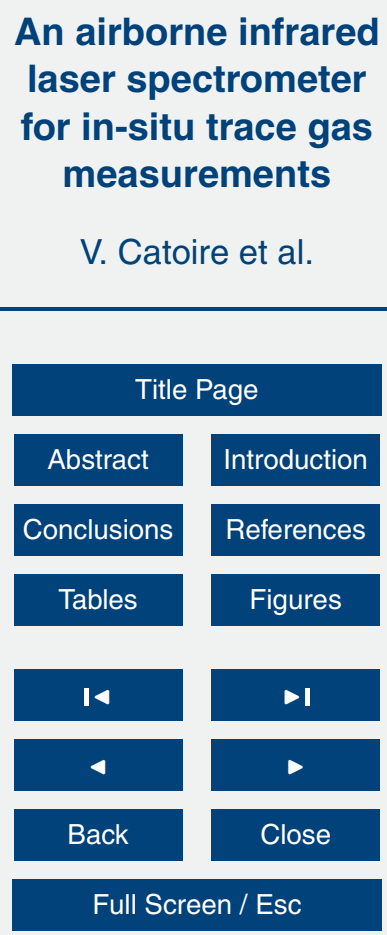

Printer-friendly Version

Interactive Discussion 


\section{Introduction}

Infrared (IR) absorption spectroscopy is among the fastest on-line measurement methods of atmospheric trace gases. Using lasers leads to ultra-high spectral resolution $\left(<10^{-3} \mathrm{~cm}^{-1}\right)$, and therefore larger sensitivity and selectivity than lower resolution IR 5 method such as Fourier Transform IR (FTIR) spectroscopy. A tunable laser spectrometer essentially consists of one or several laser sources, an optical cell where the trace gas is sampled, a photodetector and the electronic system controlling the laser(s) and the data acquisition. This leads to a very compact instrument with high frequency (in a few seconds or less) and accurate measurements. In principle the laser is tuned over 10 a spectral micro-domain $\left(<1 \mathrm{~cm}^{-1}\right)$ to match wavenumbers $\widetilde{v}_{0}$ of the ro-vibrational lines of the molecules in question. In order to perform ultra-high resolution spectroscopy, the pressure of the analysed air is reduced to $\sim 10-50 \mathrm{hPa}$ in a closed cell. The BeerLambert law relationship, Eq. (1), provides quantitative results relevant to atmospheric studies, i.e. volume mixing ratios (vmr; unitless), based on spectroscopic molecular 15 parameters and measured quantities:

$\mathrm{vmr}=\frac{-10^{6} k_{\mathrm{B}} T \ln \left(/(\widetilde{v}) / I^{\circ}(\widetilde{v})\right)}{p L S g\left(\widetilde{v}-\widetilde{v}_{0}\right)}$

where $k_{\mathrm{B}}$ is the Boltzmann constant (units of $\mathrm{JK}^{-1}$ ), $T$ is the temperature $(\mathrm{K}), I(\widetilde{v}) / I^{\circ}(\widetilde{v})$ is the transmission at a particular wavenumber $\widetilde{v}, p$ is the total pressure $(\mathrm{Pa})$ of the cell containing the sampled molecules, $L$ is the optical path length $(\mathrm{cm}), S$ is the line intensity ( $\mathrm{cm}$ molecule ${ }^{-1}$ ) of the molecule depending on the partition functions, the temperature and the lower-state energy $E^{\prime \prime}$ of the transition, and $g\left(\widetilde{v}-\widetilde{v}_{0}\right)$ is the normalized line profile $(\mathrm{cm})$ at $\widetilde{v}$ around the wavenumber of the transition line $\widetilde{v}_{0}$, most frequently assumed to be a Voigt one in the HITRAN spectroscopic database (Rothman et al., 2013). The Voigt profile is the convolution of the Doppler (Gaussian) profile (with $T$

ing on the pressure $p$, the air-broadened half-width $\gamma_{\text {air }}$, and the temperature $T$ with
AMTD

8, 9165-9207, 2015

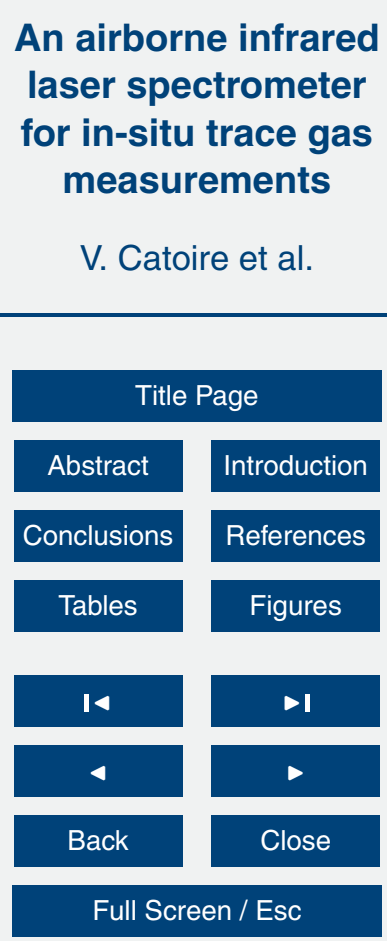

Printer-friendly Version

Interactive Discussion 
the temperature-dependent coefficient $n_{\text {air }}$ (Fried and Richter, 2006). Absorption measurements are thus considered absolute and do not require a calibration if accuracy is expected to be about that of the spectroscopic database. An overview of this technique was given by Fried and Richter (2006). In addition, Fried et al. (2008) and McQuaid 5 et al. (2013) recently reviewed the implementation of this technique in aircraft.

Until the 2000s, Tunable Diode Laser Absorption Spectroscopy (TDLAS) using leadsalt diode lasers were widely used in the main part of the mid-infrared (MIR) domain $(3-12 \mu \mathrm{m})$. In this domain, molecules are active for the fundamental transitions, which leads to the strongest absorptions and therefore detection capabilities. TDLAS has 10 been successfully applied to airborne measurements even recently, for instance for $\mathrm{CH}_{4}, \mathrm{~N}_{2} \mathrm{O}, \mathrm{CO}, \mathrm{HCHO}$ and $\mathrm{H}_{2} \mathrm{O}$ and isotopes (see, e.g., Wienhold et al., 1998; Scott et al., 1999; Kormann et al., 2002; Bartlett et al., 2003; de Reus et al., 2003; Wert et al., 2003; Viciani et al., 2008). However tunable lead-salt laser diodes are at present surpassed by a new type of lasers - the Quantum Cascade Lasers (QCLs) - that has 15 advantageous properties (Curl et al., 2010). QCLs present better reproducibility for the wavelength emission domain and the optical output power, possess pure single resonant mode, operate at a single frequency using a distributed feedback (DFB) structure, and have a wider range of wavenumber tunability $\left(\mathrm{a}\right.$ few $\left.\mathrm{cm}^{-1}\right)$, which could potentially lead to more species to detect. They also possess much higher optical output power (>1 mW), which is useful for long optical path operation. In addition QCLs are now operated near room temperature (RT) and so, small Peltier thermoelectric coolers can replace large $\mathrm{N}_{2}$ dewars. QCLs have thus been applied to airborne measurements of trace gases in pulsed mode, for instance for $\mathrm{HCHO}, \mathrm{HCOOH}, \mathrm{CH}_{4}, \mathrm{CO}, \mathrm{CO}_{2}, \mathrm{~N}_{2} \mathrm{O}$ and $\mathrm{H}_{2} \mathrm{O}$ (Herndon et al., 2007; Lopez et al., 2008; Kort et al., 2011; Wecht et al., 2012; Santoni et al., 2014). QCLs can also be operated in continuous wave (CW) mode instead of pulsed mode, resulting in negligible linewidths $\left(\mathrm{HWHM}<2 \times 10^{-4} \mathrm{~cm}^{-1}\right.$; McManus et al., 2006; Guimbaud et al., 2011) with respect to the molecular absorption line, and thus leading to measurements of higher accuracy and sensitivity. However, as far as we know, only Yacovitch et al. (2014) have published work on the use of CW QCLs in

\section{AMTD}

8, 9165-9207, 2015

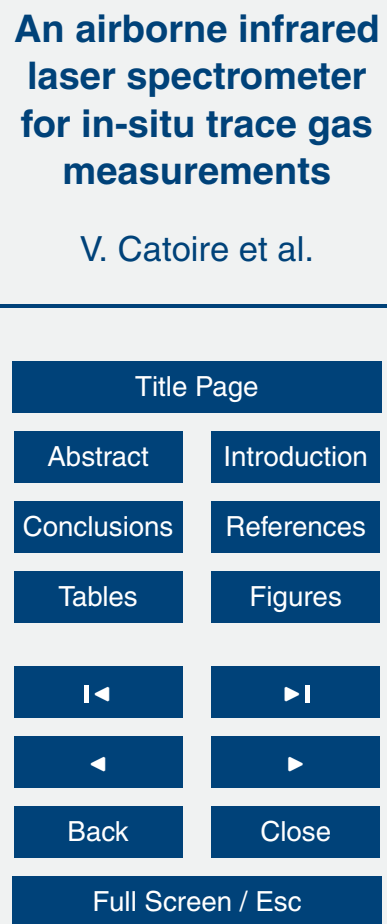

Printer-friendly Version

Interactive Discussion 
aircraft until now. Very recently, Interband Cascad Lasers (ICLs) appeared as serious alternatives to QCLs for MIR measurements due to less power requirement for laser emission threshold and better energy efficiency leading to easier use because of less cooling requirement. However their application to airborne is also still limited (Chris5 tensen et al., 2007), in particular because they are presently restricted to emission in the 3-6 $\mu \mathrm{m}$ band.

In the near-infrared (NIR) domain $(0.8-2.5 \mu \mathrm{m})$ benefitting from telecommunication developments, TDLAS has employed DFB InGaAs diode laser sources from the 2000s, with similar properties as QCLs and ICLs, but at a lower cost, and more recently DFB InaAssb lasers allowed for extension toward $3 \mu \mathrm{m}$. Since line intensities are much lower in the NIR than in the MIR, measurements essentially concern molecules of higher abundances, i.e. $\mathrm{H}_{2} \mathrm{O}, \mathrm{CO}_{2}$ and $\mathrm{CH}_{4}$ and their isotopes (see e.g., D'Amato et al., 2002; Podolske et al., 2003; Durry et al., 2007; Zondlo et al., 2010; Rollins et al., 2014; Dyroff et al., 2015).

15 In parallel, significant advances have been performed in the design of optical absorption cells coupled to the laser sources. Several types of multiple reflection cells have been used, leading to long optical paths, e.g. the Herriott cell (see e.g., Fried et al., 1999; Moreau et al., 2005), the astigmatic Herriott cell (Fried et al., 2003; Herndon et al., 2007; McManus et al.; 2011), the Robert cell (Robert, 2007). Finally one should be aware of the recent development of other types of airborne infrared laser absorption spectrometers, i.e. those using resonant cavities instead of non-resonant ones just mentioned. This concerns Cavity Ring Down Spectroscopy (CRDS; McQuaid et al., 2013), Cavity Enhanced Absorption Spectroscopy (CEAS) (Bertseva et al., 2002; Kerstel et al., 2006; Hendriks et al., 2008), and Off Axis Integrated Cavity Output Spectroscopy (OA-ICOS) aboard unmanned aerial vehicle (Berman et al., 2012) or commercial passenger aircrafts (Dyroff et al., 2014).

In the present paper, we describe a newly built airborne instrument called SPIRIT (SPectromètre Infra-Rouge In situ Toute altitude), performing ultra-high resolution infrared absorption spectroscopy thanks to the use of three MIR CW-DFB-RT-QCLs cou-

\section{AMTD}

8, 9165-9207, 2015

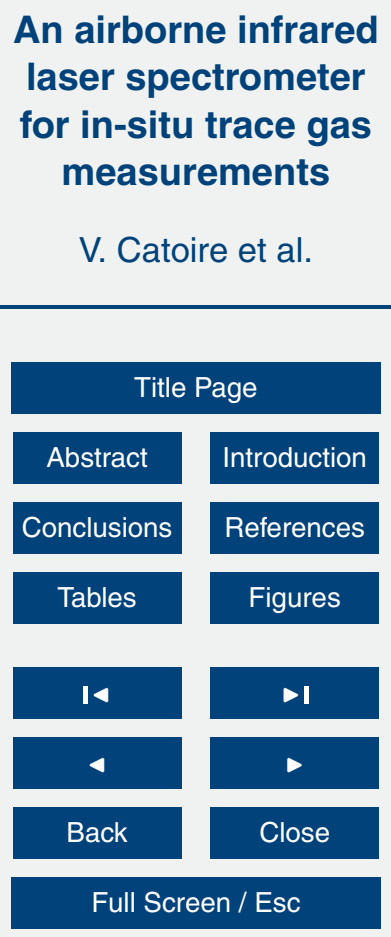

Printer-friendly Version

Interactive Discussion 
pled with the non-resonant Robert cell. This leads to quantify in-situ abundances of at least three atmospheric trace gases, which can be different by only changing the QCL, depending on the objectives of each project. In Sect. 2 we present the optomechanical setup and the control-acquisition electronics of the instrument, and the 5 data retrieval process, followed by characterisation of its performances. First examples of measurements obtained during the campaign associated to the SHIVA (Stratospheric Ozone: Halogen Impacts in a Varying Atmosphere) FP7 European project in November-December 2011 are given in Sect. 3. In total, sixteen flights were performed from Miri (Malaysia) airport in Northwest Borneo by the Falcon-20 research aircraft 10 operated by the German Aerospace agency DLR (Deutsches Zentrum für Luft- und Raumfahrt), covering a wide geographical range $\left(1-8^{\circ} \mathrm{N}, 102-122^{\circ} \mathrm{E}\right)$ and a vertical range from the planetary boundary layer up to the ceiling altitude of $13 \mathrm{~km}$. One of the objectives of this project was the investigation of atmospheric transport of Very Short-Lived Species (VSLS) from the boundary layer to the upper troposphere. In 15 fact, in the last decades, some observational campaigns (such as SHIVA and TC4 (http://rtmm.nsstc.nasa.gov/tc4.html)) and/or modelling studies were focused on determining the contribution of the VSLS such as halogenated VSLS $\left(\mathrm{CHBr}_{3}, \mathrm{CH}_{2} \mathrm{Br}_{2}\right.$, $\mathrm{CH}_{3} \mathrm{I}$...: Tegtmeier et al., 2013; Hossaini et al., 2012) or DMS (Marandino et al., 2013) on the bromine and sulphur budgets in the upper troposphere and lower stratosphere (UTLS). These species' abundances in the UTLS are closely dependent on the efficiency of the transport by convection in tropical regions. Observational campaigns can only address these questions in a limited way: limited in time, in space and in altitude. Consequently, the role of deep convection on trace gas transport has to be studied by modelling. However, field campaign are essential to support model improvements by comparing measurements or/and calculation of the transport efficiency. Some observational studies at mid-latitudes (Bertram et al., 2007) and in the tropics (Ray et al., 2004) reported effective transport of trace gases (Bechara et al., 2010) and even short-lived species (Cohan et al., 1999) by convection, showing that between 20 to $40 \%$ of air came from the ground. We present here two meteorological convection cases associ-

\section{AMTD}

8, 9165-9207, 2015

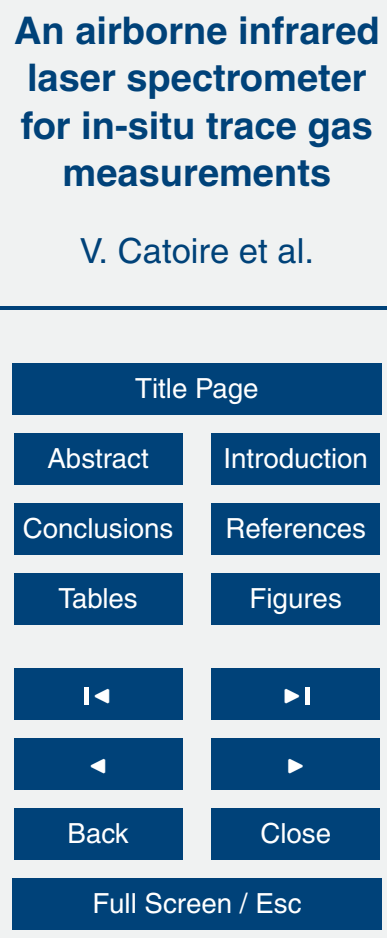

Printer-friendly Version

Interactive Discussion 
ated with several sudden observed increases of $\mathrm{CO}$ and $\mathrm{CH}_{4}$ originating from ground pollution when the airplane went through the anvils of convective cumulus. The $\mathrm{CO}$ trace gas proved to be a particularly good tracer of this phenomenon and lead, for this study, to the quantification of the fraction of air originating from ground level.

\section{Experimental method}

\subsection{Instrument design}

The general principle of the instrument functioning for a single channel (one QCL) and the process to retrieve volume mixing ratios have already been described previously (Guimbaud et al., 2011). This concerned greenhouse gas $\left(\mathrm{CH}_{4}, \mathrm{~N}_{2} \mathrm{O}\right)$ flux mea10 surements at the geosphere-atmosphere interface (Gogo et al., 2011). The following description only deals with the aspects of the airborne version and summarizes the essential points of the ground version in order to make the rest of the paper understandable. In brief, the high measurement time resolution (1.6s) leading to high spatial resolution, the number $(\geq 4)$ and versatility of the trace gases to be quantified with 15 high precision and accuracy (a few \%) and very good sensitivity, and the easy retrieval process (with preliminary results on-line) are the main advantages of SPIRIT. Several photographs of the instrument integrated in the Falcon-20 aircraft rack and a layout of its functioning principle are shown in Fig. 1 and 2. SPIRIT weighs $102 \mathrm{~kg}$ and measures $95.8 \mathrm{~cm}$ in height, $65.4 \mathrm{~cm}$ in width and $55.9 \mathrm{~cm}$ in depth.

SPIRIT operates with three distributed feedback quantum cascade lasers (DFBQCLs from Alpes Lasers), corresponding to the three measurement channels, coupled to one optical cell and two detectors only - one for the measurement channels and the other one for the reference channel. The main electronic module receives commands from a laptop computer via a RS-232 link and drives the current and temperature controllers for each of the three QCLs. Each temperature controller consists of a Peltier thermoelectric module that maintains each laser chip at a constant temperature, rang-
AMTD

8, 9165-9207, 2015

An airborne infrared laser spectrometer for in-situ trace gas measurements

V. Catoire et al.

Title Page

Abstract Introduction

Conclusions References

Tables Figures

14 4 Back

Printer-friendly Version

Interactive Discussion 
ing from -31 to $+31{ }^{\circ} \mathrm{C}$ with a typical precision of $1 \mathrm{mK}$, allowing for laser single-mode emission at a precise wavenumber. A water-glycol circuit regulated at a constant temperature of $13^{\circ} \mathrm{C}$ is used for cooling each Peltier thermoelectric cooler and the Stirling detector cooler, using a liquid pump (Ecocirc Laing) and a liquid-air thermal ex5 changer (LA-115 Laird Technologies). For each QCL, a spectral micro-domain is swept by applying during $4.1 \mathrm{~ms}$ a saw-tooth ramp of several $\mathrm{mA}$ repeated at $81 \mathrm{~Hz}$ by the current controller. The micro-windows used for the present study are indicated in Table 1, with the temperature of the QCLs and the electrical currents and ramps applied. This allows for measurements of $\mathrm{CO}$ at $2179.772 \mathrm{~cm}^{-1}, \mathrm{CH}_{4}$ at $1249.627 \mathrm{~cm}^{-1}, \mathrm{~N}_{2} \mathrm{O}$ at $101249.668 \mathrm{~cm}^{-1}$, and $\mathrm{CO}_{2}$ at $2064.417 \mathrm{~cm}^{-1}$. The three QCLs work one third of the time sequentially, triggered and synchronized by the data acquisition system. One hundred and ten measurement spectra followed by eight reference spectra are acquired and averaged. With a ramp current repeated at $81 \mathrm{~Hz}$ frequency, this gives a measurement period of $1.6 \mathrm{~s}$ per laser, including the data processing and the transfer to the laptop 15 computer. The data are stored on the computer for accurate retrievals of the trace gas concentrations afterward.

The optical bench is presented in Fig. 3. The main mechanical component is a $5 \mathrm{~cm}$ thick aluminium honeycomb composite panel vertically oriented. It is inserted in the aircraft rack with vibration-shock absorbers suitably dimensioned to the airplane ac20 celeration requirements. In these conditions the maximum bench moving is less than $3 \mathrm{~cm}$. The optical cell is made of a glass tube $(8 \mathrm{~cm}$ outside diameter, $3 \mathrm{~mm}$ thick, $62.5 \mathrm{~cm}$ length) in borosilicate low thermal expansion material. The two tube ends are bonded in two adapted thermal expansion pieces. The optical cell is rigidly fixed on the upper end to the optical bench and the lower end is free to glide on a V-shaped mount in order to avoid constraint due to the different thermal expansions between aluminium and glass. The QCL housings include off-axis parabolic mirrors of $5 \mathrm{~mm}$ focal length, mounted on the same thermoelectrically-cooled copper mechanical support as the laser itself for optical alignment stability. All three laser beams, symbolized by red rays in Fig. 3, go out from these housings through an anti-reflection (ZnSe coated) win-
AMTD

8, 9165-9207, 2015

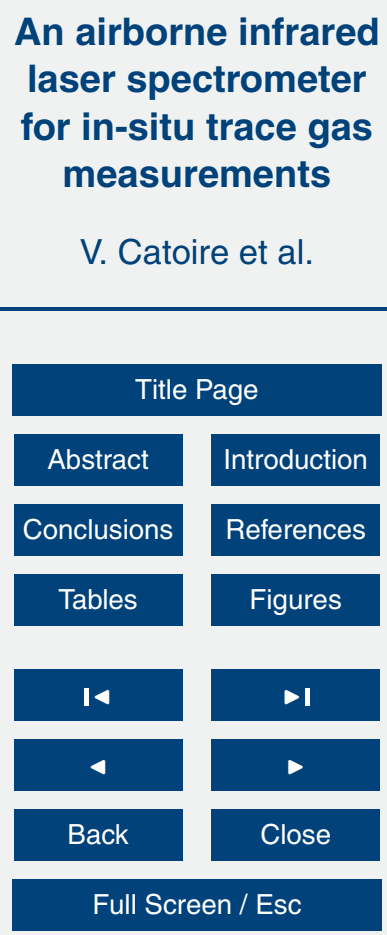

Printer-friendly Version

Interactive Discussion 
dow. An optical multiplexor allows for collecting toward a single exit the three beams which then go out to $\mathrm{BaF}_{2}$ beam splitter (BS), dividing them in two parts. A minor part is reflected toward a home-made Fabry-Pérot interferometer etalon used as reference channel for relative wavenumber calibration. A small optical reference cell containing 5 known gaseous species can be added on a second path of this channel for retrieving absolute wavenumber scale. This beam is then focused onto a photovoltaic HgCdTe detector (Judson J19D10) by a spherical mirror. The major part of the beam is directed and focused at the entrance of the multipass optical cell through a $\mathrm{BaF}_{2}$ window. The measurement output beam also goes through a second $\mathrm{BaF}_{2}$ window and is then col10 lected by a flat mirror and focused onto an analogous detector by a spherical mirror similar to the reference beam. Both detectors are cooled by the same Stirling cycle cooler (RM2 Thalès Cyrogénie) mounted in a home-made Dewar in which vacuum is maintained by passive pumping using high porosity sintered materials (CapaciTorr ${ }^{\circledR} \mathrm{D}$ 100 Saes Getters). The detected electrical signals are amplified first by pre-amplifiers 15 with a fixed gain and secondly by an automatically self-adjusted gain in the main electronic module, and digitized by a 16-bit analog-to-digital converter.

The optical cell is a patented multiple-reflection cell detailed in a previous paper (Robert, 2007). In brief, this cell is composed of three mirrors combining the design of the Herriott and White cells, which results in very easy and stable operating conditions and allows for very long optical paths, i.e. $151.00 \mathrm{~m}$ (233 reflections) or $134.22 \mathrm{~m}$ (207 reflections) in the present experiments, in a compact volume $(2.77 \mathrm{~L}$ for a cylinder of $3.7 \mathrm{~cm}$ radius and $64.5 \mathrm{~cm}$ length). This cell is controlled by two high-performance piezoelectric actuators (Newport PZA12) located at each of its ends, shown in Fig. 3 (in orange colour), allowing optical alignment at the desired path number and also the change in the path number by tilting the two mirrors relative to each other. A third actuator (not visible in Fig. 3 ) is used to move slowly $(0.3 \mathrm{~Hz})$ back and forth the stand-alone mirror on a small range, efficiently attenuating the optical interference fringes. The cell temperature is measured by a Pt100 resistance probe with a precision of $0.01 \mathrm{~K}$, and is estimated to be accurate and homogeneous in the cell within $0.5 \mathrm{~K}$, leading to $0.2 \%$

\section{AMTD}

8, 9165-9207, 2015

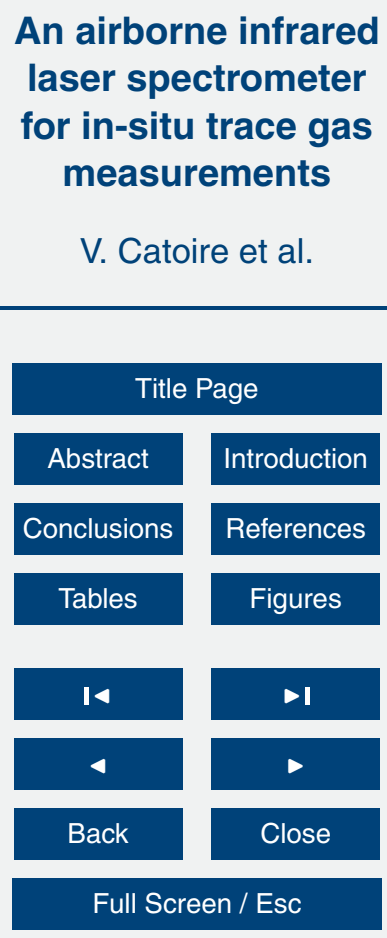

Printer-friendly Version

Interactive Discussion 
error maximum in the gas volume mixing ratios (vmr) derived, as previously determined in a sensitivity analysis (Guimbaud et al., 2011). Air is sampled through a rear-facing stainless steel inlet of $16 \mathrm{~mm}$ inside diameter (i.d.), placed in front of the aircraft on the roof of the cabin in order to avoid contamination. A $1 / 2^{\prime \prime}(12.7 \mathrm{~mm})$ i.d. PFA Teflon tube 5 is inserted inside this inlet and connected via a $6 \mathrm{~mm}$ o.d. (Swagelock) stainless steel valve to a pressure regulator (MKS 649) upstream of the cell. It is known that using these materials leads to negligible adsorption of the trace gases to detect on the walls of the sampling tube. Air is continuously drawn through the optical cell using a scroll pump (XDS10 Boc Edwards) fixed with vibration absorbers on the Falcon aircraft rack.

10 The pressure is maintained constantly reduced in the range $30-40 \mathrm{hPa}$ by the pressure regulator, accurately known $( \pm 0.1 \mathrm{hPa})$ using a $0-100 \mathrm{hPa}$ gauge (DTM Scaime), and the flow is adjusted by a manually actuated dosing valve (EVN116 Pfeiffer) located at the cell output, upstream of the pump, as shown in Fig. 2. This leads to an effective flow rate of $0.32 \mathrm{Ls}^{-1}$ in the cell at $35 \mathrm{hPa}$ (or 0.60 standard litre per minute (SLM)), 15 measured by the mass flowmeter combined with the pressure regulator. A maximum estimated uncertainty of $0.2 \mathrm{hPa}$ influences the accuracy of the inferred vmr by $0.3 \%$ (Guimbaud et al., 2011). The exit line of the vacuum pump is connected to the exhaust tube on the floor of the aircraft.

Once switched on, SPIRIT operates fully automated measurements. In order to compensate for any dimensional drifts, optical realignment is regularly performed by using the two piezoelectric actuators, whose frequency can be chosen, e.g. every $10 \mathrm{~min}$ in the present experiments. A GPS system (Garmin GPS18) giving universal time, altitude, latitude and longitude is implemented on which the laptop computer is synchronized. This has proven to be very useful for the data interpretation, enabling easy comparison with the data of the aircraft and the other scientific instruments on board. Finally, it should be underlined that the materials and functioning of the SPIRIT instrument fulfil the international regulations concerning aircraft equipment and led to certification for installation in the Falcon-20 (established by Enviscope $\mathrm{GmbH}$ ).

\section{AMTD}

8, 9165-9207, 2015

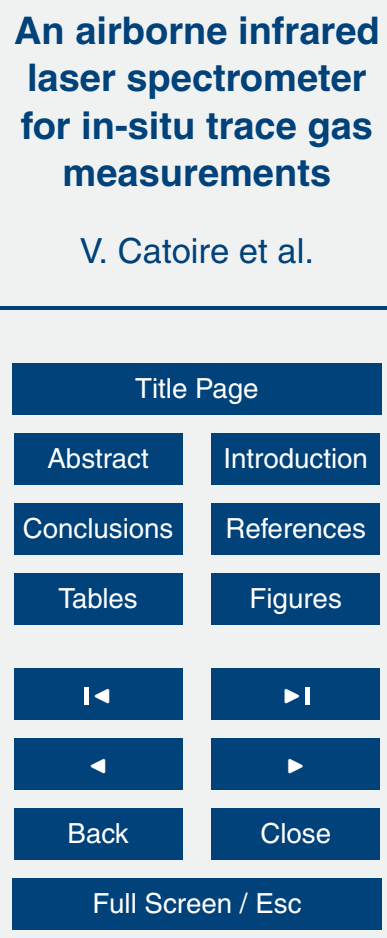

Printer-friendly Version

Interactive Discussion 


\subsection{Data retrieval}

The data retrieval is based on Beer-Lambert law, Eq. (1). As previously explained in detail (Guimbaud et al., 2011; Moreau et al., 2005), it consists in fitting the numerical second derivative of the experimental transmission $I(\widetilde{v}) / I^{\circ}(\widetilde{v})$ to that of the 5 simulated transmission, $\exp \left[-L \cdot S \cdot g\left(\widetilde{v}-\widetilde{v}_{0}\right) \cdot C\right]$, at each wavenumber $\widetilde{v}$ of the spectral micro-window by adjusting the molecular concentration $C$ (molecules $\mathrm{cm}^{-3}$ ). The selected micro-windows were usually $2179.70-2179.85 \mathrm{~cm}^{-1}, 1249.56-1249.73 \mathrm{~cm}^{-1}$, and 2064.30-2064.55 $\mathrm{cm}^{-1}$ for $\mathrm{CO}, \mathrm{CH}_{4}$ and $\mathrm{N}_{2} \mathrm{O}$, and $\mathrm{CO}_{2}$, respectively. A linear least-squares algorithm minimizes the residual, i.e. the difference between the exper10 imental and simulated signal. The volume mixing ratio vmr is subsequently deduced from $C$ by knowing the total pressure $p$ and the temperature $T$ of the optical cell. The second derivative method has the advantage of not needing the accurate reconstruction of the $100 \%$ transmission baseline (the continuous component of the signal) where the molecules absorb, and of reducing the optical interference fringes. Both methods give similar results in the present case for which the maximum optical absorptions $\left(1-I\left(\widetilde{v}_{0}\right) / I^{\circ}\left(\widetilde{v}_{0}\right)\right)$ are significant, typically $4 \%$ for $\sim 100$ ppbv CO, $4 \%$ for $1.8 \mathrm{ppmv} \mathrm{CH}_{4}$, $1 \%$ for $325 \mathrm{ppbv} \mathrm{N}_{2} \mathrm{O}$ and $7 \%$ for $400 \mathrm{ppmv} \mathrm{CO}_{2}$. The second derivative method is especially more effective in the case of low absorption (Moreau et al., 2005). Figures 4 A, B, C show examples of spectra for $\mathrm{CO}, \mathrm{CH}_{4}, \mathrm{~N}_{2} \mathrm{O}$ recorded during one of the two case studies, on the 9 December 2011, and for $\mathrm{CO}_{2}$ during a transfer flight to Malaysia, on the 8 November 2011. Statistical errors represented by the root mean square noise at $1 \sigma$ confidence level on the fitting retrievals are indicated in Fig. 4. They are typical of the measurements during this campaign, which were on average $1 \%$ for $\mathrm{CO}, 1 \%$ for $\mathrm{CH}_{4}, 3 \%$ for $\mathrm{N}_{2} \mathrm{O}$ and $1 \%$ for $\mathrm{CO}_{2}$.

25 Due to a failure of the air conditioning system of the aircraft from the first flight during the campaign (16 November), the QCL corresponding to $\mathrm{CO}_{2}$ measurement could not be maintained at $-20.5^{\circ} \mathrm{C}$ and broke down. Consequently the whole campaign
AMTD

8, 9165-9207, 2015

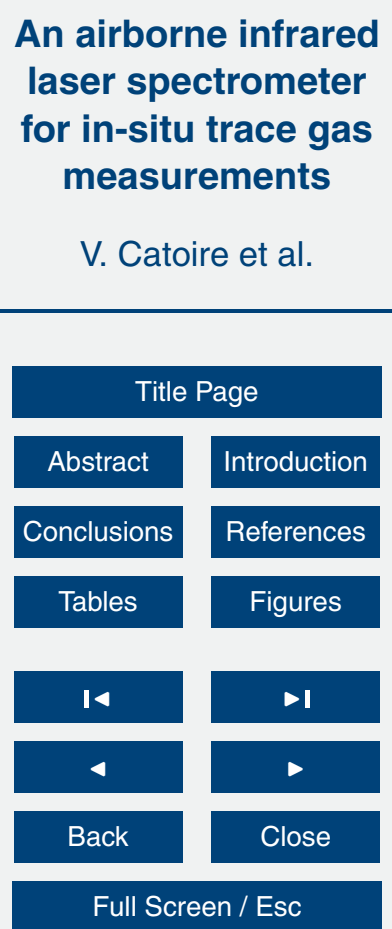

Printer-friendly Version

Interactive Discussion 
took place without measurements of this species, and in particular no $\mathrm{CO}_{2}$ data were obtained on 19 November and 9 December.

\subsection{Performances of the instrument}

The performances of SPIRIT in terms of linearity, limit of detection, dynamic measuring 5 range, sensitivity, accuracy, and response time have been studied in detail in laboratory, essentially after the SHIVA campaign. The characterisation of the $\mathrm{CO}_{2}$ measurements is therefore not much presented.

Response time has been evaluated by subjecting the instrument to sudden positive and negative variations of carbon monoxide mixing ratio in dry air from 2 to $102 \mathrm{ppbv}$.

10 The mean rise time between 10 and $90 \%$ of the step, $8.6 \pm 0.3 \mathrm{~s}$, is consistent with the fall time, $8.8 \pm 0.3 \mathrm{~s}$, for a standard flow rate of $0.60 \mathrm{SLM}$. These values correspond to the theoretical overall flush time $(8.7 \mathrm{~s})$ of the cell, showing the absence of dead volumes that could affect the instrument accuracy. This response time can ultimately be lowered to $5.8 \mathrm{~s}$ for 0.90 SLM flow rate. Higher flows led to lower uncontrolled cell pres15 sures at the highest altitudes where ambient pressure decreases to less than $250 \mathrm{hPa}$. The leak rate is about $1.1 \times 10^{-3} \mathrm{hPa} \mathrm{Ls}^{-1}$ and represents $1.4 \times 10^{-4}$ to $8.1 \times 10^{-5}$ times the sampled gas flow rate. Considering the worst case for which the ambient gas concentration is greater than that of the sampled air by one order of magnitude (in the aircraft cabin), the relative error from leaks should not be greater than $0.15 \%$.

20 The linearity of the measurements has been determined using a gas cylinder containing about $300 \mathrm{ppbv}$ of carbon monoxide with different values of dilution in dry air free of CO. Contrary to the use of individual gas cylinders of different concentrations, the use of such a method makes unnecessary the need to know the concentration of the reservoir bottle with high accuracy and eliminates a source of uncertainty since 25 the potential relative bias on the knowledge of the concentration is the same for all dilution values. Figure 5 illustrates this linearity, with the deduction of the square of the correlation coefficient $R^{2}=0.99996$. The residual shows no particular deviation from linear adjustment, with a standard deviation $1 \sigma=0.65$ ppbv deduced from 3500 sep-
AMTD

8, 9165-9207, 2015

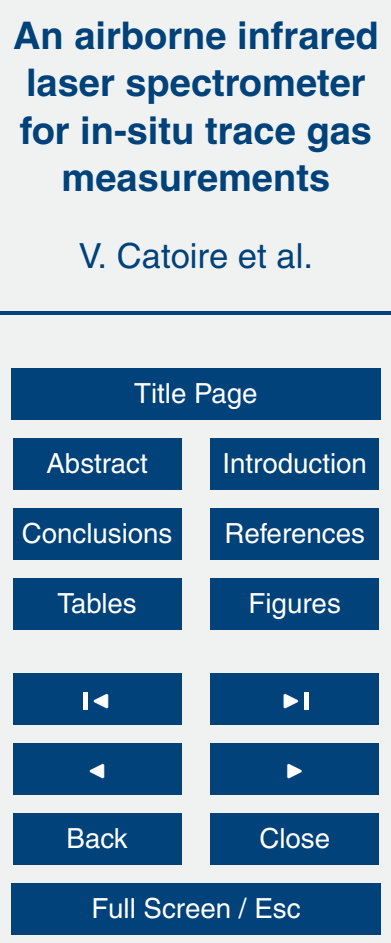

Printer-friendly Version

Interactive Discussion 
arate data. Similar performances are expected for non-sticky molecules such as $\mathrm{CH}_{4}$, $\mathrm{N}_{2} \mathrm{O}$ and $\mathrm{CO}_{2}$ since only the line intensity and the QCL differ with respect to CO channel, implying no impact on the linearity, contrary to the optical path and the detection system, which are identical.

5 Lower limits of detection have been experimentally determined for each gas. It is reached when the optical absorption signal is equal to the root mean square noise $(1 \sigma)$ measured on the spectrum residual. At this point the relative error on the fit is considered to be $100 \%$ (signal-to-noise ratio $=1$ ) and prevails on every other uncertainty contribution. Limits of detection are $0.6 \mathrm{ppbv}$ for $\mathrm{CO}, 9.0 \mathrm{ppbv}$ for $\mathrm{CH}_{4}$ and $5.3 \mathrm{ppbv}$ for ${ }_{10} \mathrm{~N}_{2} \mathrm{O}$, as shown in Fig. 6. Fits are generalized hyperbolas describing the linear progression of uncertainties with respect to vmr for low values where the noise on the spectra is predominant. The error stagnations at higher concentrations illustrate the fact that the fitting errors prevail on other sources of uncertainty. Increases of relative errors (vertical scatter visible in Fig. 6) were occasionally observed, due to the regular auto15 matic optical realignments. At the other end of the range, considering a spectrum can still be accurately fitted until the optical absorption at the maximum of the transition line $\widetilde{v}_{0}$ reaches $90 \%$ (i.e. $10 \%$ transmission), one can calculate upper limits of detection for CO: $4.5 \mathrm{ppmv}, \mathrm{CH}_{4}$ : $110 \mathrm{ppmv}$, and $\mathrm{N}_{2} \mathrm{O}: 60 \mathrm{ppmv}$, using simulations taking into line intensities and the experimental conditions. Dynamic measuring ranges of about four decades are thus deduced.

Sensitivity is considered to be the lowest vmr variation the instrument is able to detect reliably over a noisy background. As it depends on the duration for which the variation observation is carried out, the Allan deviation $\sigma_{\mathrm{A}}$ constitutes a relevant figure of merit. This deviation is calculated for non-varying sampled gas concentration. Depending on the degree of certainty required to qualify a variation in $\mathrm{vmr}$ as real, one can chose as criteria 1 to $3 \sigma_{\mathrm{A}}$. Figure 7 illustrates the Allan deviations for $\mathrm{CO}, \mathrm{CH}_{4}, \mathrm{~N}_{2} \mathrm{O}$ and $\mathrm{CO}_{2}$ until $365 \mathrm{~s}$ obtained in laboratory. As expected, the experimental decays are significant, but smaller than the ideal white noise slopes. The minima of these $\sigma_{\mathrm{A}}$ Allan deviations are all reached around $100 \mathrm{~s}$, with values of about $0.13 \mathrm{ppbv}(2 \%)$ for $\mathrm{CO}$,

\section{AMTD}

8, 9165-9207, 2015

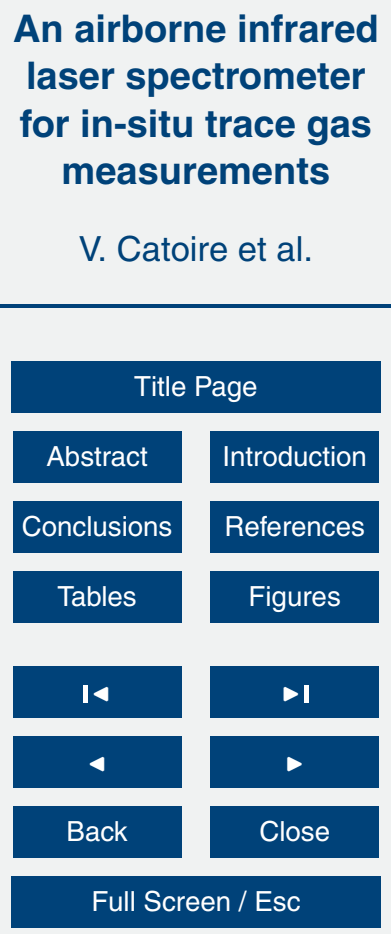

Printer-friendly Version

Interactive Discussion 
$1.3 \mathrm{ppbv}(0.8 \%)$ for $\mathrm{CH}_{4}, 0.8 \mathrm{ppbv}$ for $\mathrm{N}_{2} \mathrm{O}\left(3 \%\right.$ ) and $0.3 \mathrm{ppmv}(0.7 \%)$ for $\mathrm{CO}_{2}$. The intermediate values at $10 \mathrm{~s}$ are noted since this is the typical response time in flight. It is thus expected to detect $\left(1 \sigma_{\mathrm{A}}\right)$ variations higher than $0.2 \mathrm{ppbv}$ for $\mathrm{CO}, 4 \mathrm{ppbv}$ for $\mathrm{CH}_{4}$ and 2 ppbv for $\mathrm{N}_{2} \mathrm{O}$ in flight. The lower performance for $\mathrm{N}_{2} \mathrm{O}$ is due to lower op5 tical absorption and thus lower signal-to-noise ratio (improvement can be realised by just changing the spectral domain or the QCL for a larger line intensity). For averages of more than $100 \mathrm{~s}$, it is clearly seen that the deviations increase, though remaining below the precision obtained for $1.6 \mathrm{~s}$ averaging. Of course in-flight instantaneous $1 \sigma$ precisions determined by the spectral fitting error in the previous Sect. 2.2 (1 ppbv for $10 \mathrm{CO}, 18 \mathrm{ppbv}$ for $\mathrm{CH}_{4}$ and $10 \mathrm{ppbv}$ for $\mathrm{N}_{2} \mathrm{O}$ ) are somewhat greater than the $1 \sigma_{\mathrm{A}}$ sensitivities at $1.6 \mathrm{~s}\left(0.4 \mathrm{ppbv}\right.$ for $\mathrm{CO}, 6 \mathrm{ppbv}$ for $\mathrm{CH}_{4}$ and $2.4 \mathrm{ppbv}$ for $\mathrm{N}_{2} \mathrm{O}$ ) deduced from the statistical distribution of 228 measurements (365 s) because fitting errors include some permanent pattern due to, for instance, Fabry-Perot interference fringes and differences between experimental and simulated line profiles.

15 For the gas concentrations studied here, the total, without calibration, uncertainty is largely due to the accuracy with which the spectroscopic parameters are known. For the absorption lines used in SPIRIT, the HITRAN database (Rothman et al., 2013) provides line intensities $S$ and air-broadened half-widths $\gamma_{\text {air }}$, with an accuracy of better than $5 \%$, affecting the vmr accuracy on the same order for the former and two times less for the latter $(2.5 \%)$; other uncertainties on spectroscopic parameter have negligible impacts (Guimbaud et al., 2011). Taking into account other uncertainty sources $(0.3 \%$ on pressure and $0.2 \%$ on temperature: see above Sect. 2.1 ; and the retrieval fitting errors), the estimated accuracies calculated as the square root of the quadratic sum are $5.7 \%$ for $\mathrm{CO}$ and $\mathrm{CH}_{4}$ and $6.4 \%$ for $\mathrm{N}_{2} \mathrm{O}$. Since the most influent parameter, i.e. the line intensity, is an intrinsic value of the molecules, it does not vary with the measurement conditions and can result in a constant bias on vmr estimation. In order to determine this bias, more than 850 measurements of a calibrated gas have been performed. The cylinder containing this gas mixture (Scott-Marrin Inc.) had been calibrated by the WMO GAW Central Calibration Laboratories: $102.1 \pm 0.7$ ppbv CO, $1822 \pm 3$ ppbv

\section{AMTD}

8, 9165-9207, 2015

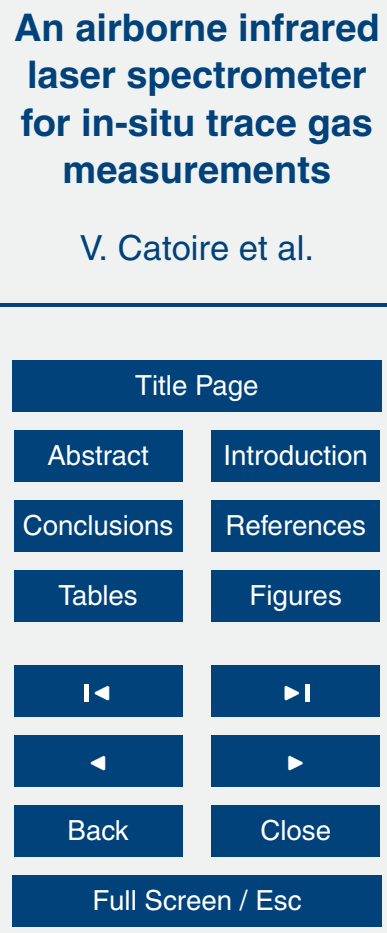

Printer-friendly Version

Interactive Discussion 
$\mathrm{CH}_{4}, 332.97 \pm 0.16 \mathrm{ppbv}$ for $\mathrm{N}_{2} \mathrm{O}$. Consistently, results presented in Fig. 8 show that the vmr of the calibrated gases measured by SPIRIT are in agreement with these calibrated values, within the estimated uncertainties: $4.6 \%$ for $\mathrm{CO}, 0.61 \%$ for $\mathrm{CH}_{4}$ and $4.5 \%$ for $\mathrm{N}_{2} \mathrm{O}$. In this case, after removing these biases, the total calculated accuracies 5 result from the square root of the quadratic sum of the uncertainty on the cylinder values quoted above and the standard deviation $(1 \sigma)$ on measurements $(0.53 \%$ for $\mathrm{CO}, 0.43 \%$ for $\mathrm{CH}_{4}, 1.1 \%$ for $\left.\mathrm{N}_{2} \mathrm{O}\right)$. The total accuracies are then $0.9 \mathrm{ppbv}(0.9 \%)$ for $\mathrm{CO}, 8.6 \mathrm{ppbv}(0.47 \%)$ for $\mathrm{CH}_{4}$, and $3.8 \mathrm{ppbv}(1.2 \%)$ for $\mathrm{N}_{2} \mathrm{O}$. Essential performances of the instrument are summarized in Table 2.

10 An in-flight intercomparison between the $\mathrm{CO}$ vmr measured by SPIRIT and by the gas filter correlation analyzer (Model 48C GFC from Thermo Environmental Instruments) at ground took place on the 11 April 2013. SPIRIT performed measurements in the french Falcon-20 aircraft from SAFIRE (CNRS-INSU-MétéoFrance) making loops around the Pic du Midi de Bigorre situated at $2877 \mathrm{~m}$ altitude, while the analyzer mea15 sured the ambient carbon monoxide from the Pic du Midi station. The GFC CO analyzer reported an average value of $\mathrm{CO}$ every 5 min mixing ratios: $117.4 \pm 6.6 \mathrm{ppbv}$ (Gheusi et al., 2011), while the mean CO vmr for SPIRIT was $113.5 \pm 6.4$ ppbv. The two values agree within the uncertainties.

\section{Results and discussion}

\subsection{Measurement campaign}

The SHIVA aircraft campaign took place in Malaysia between the 16 November and the 11 December 2011. The measurements were conducted from the DLR Falcon-20 aircraft. GPS time and location, pressure and altitude, as well as atmospheric parameters and aircraft altitude are known for each data set. Most of the landings and take-offs during the campaign were conducted from Miri airport on Borneo Island, Malaysia. The results of two flights that were performed on the 19 November and the 9 Decem-

\section{AMTD}

8, 9165-9207, 2015

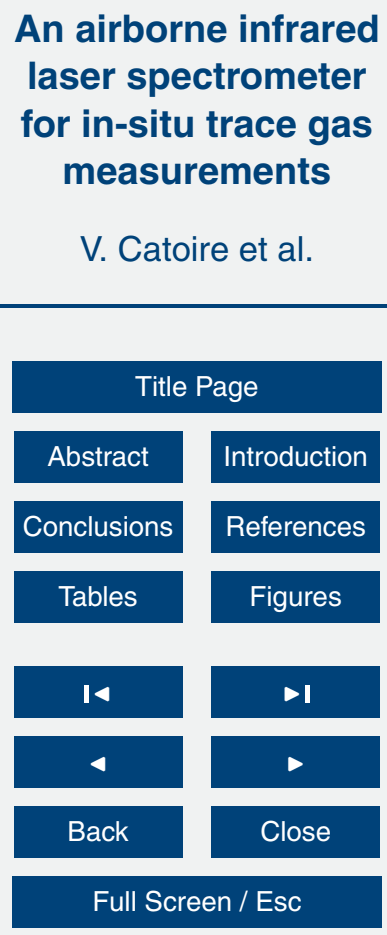

Printer-friendly Version

Interactive Discussion 
ber 2011 are presented. The flight on the 19 November began from Miri at 07:50 UTC (15:50 local time), flew North along the coast towards Kota Kinabalu, and ended at Miri at 10:10 UTC (18:10 local time). The flight on the 9 December took place between Tawau and Miri over Borneo between 08:15 UTC (16:15 local time) and 10:50 UTC 5 (18:50 local time). The $\mathrm{CO}$ vmr decreased with increasing altitude from 120-150 ppbv near the ground $(>1 \mathrm{~km})$ to $70-80 \mathrm{ppbv}$ in the free troposphere $(8-10 \mathrm{~km})$.

\subsection{In-situ measurements of $\mathrm{CO}$ and $\mathrm{CH}_{4}$ for the study of transport by deep convection}

\subsubsection{Meteorological situations of the flights}

One of the objectives of the SHIVA field campaign was to study the pathways of halogen VSLS emitted from the oceans in the boundary layer to the upper troposphere and then to the lower stratosphere, and to quantify these transport processes. The main mechanism leading to a rapid transport of air from the lower troposphere to the upper troposphere in the tropics is deep convection. This is why the SHIVA field campaign 15 took place during the early winter monsoon season. During the campaign, several Falcon aircraft flights were conducted around $11-13 \mathrm{~km}$ in altitude, in order to sample the upper troposphere in the vicinity of deep tropical convection. To highlight the application of the SPIRIT measurements for characterising the air composition in the upper troposphere, we studied the two flight measurements around $12 \mathrm{~km}$ altitude within the outHow of deep convective systems, as presented above (Sect. 3.1). Figures 9 and 10 depict the flight tracks over-plotted, respectively, on the brightness temperatures from the $11 \mu \mathrm{m}$ channel IR108 on board the Japanese geostationary multifunctional transport satellite MTSAT-2 and the corresponding cloud height estimation based on Hamada and Nishi (2010) http://database.rish.kyoto-u.ac.jp/arch/ctop/index_e.html). Brightness temperature represents thermal radiative intensity emitted by the cloud top and is used for the detection of convective activity (Iwasaki et al., 2010); this temperature decreases with increasing cloud height.

\section{AMTD}

8, 9165-9207, 2015

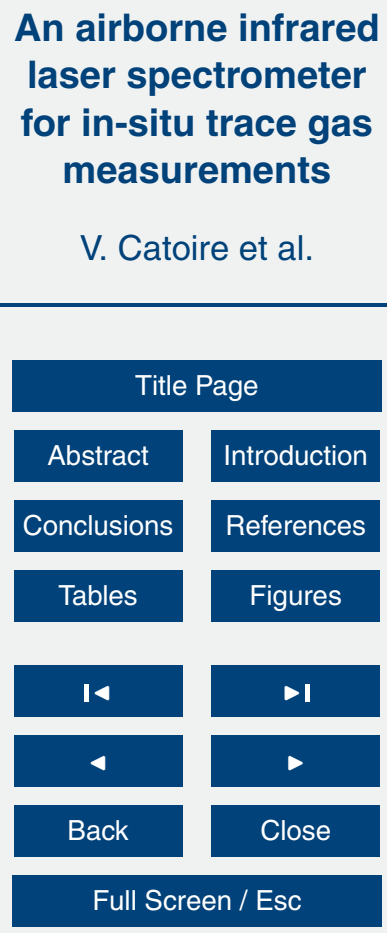

Printer-friendly Version

Interactive Discussion 
Figures 9a and 10a indicate the presence of a well-developed convective system on the 19 November located around $6^{\circ} \mathrm{N}$ and $115.5^{\circ} \mathrm{E}$ that reached a maximum of $\sim 16 \mathrm{~km}$ in altitude (Fig. 10a) with a wide anvil on its west side reaching $14.5 \mathrm{~km}$. In addition, webcam images recorded on board the aircraft (not shown; courtesy of K. Pfeilsticker 5 and K. Grossmann, Uni. Heidelberg) give strong evidence that the aircraft sampled the outflow of the convective system (anvil cloud) several times and also the surrounding upper tropospheric air. On the 9 December, a convective system with a smaller horizontal extent was detected in the satellite brightness temperatures around $5.5^{\circ} \mathrm{N}$ and $118.5^{\circ} \mathrm{E}$ (Fig. 9b). The convective part of the system reached $\sim 15.5 \mathrm{~km}$ altitude and 10 was embedded in stratiform clouds with maximum height of $\sim 13.5 \mathrm{~km}$ (Fig. 10b). For this day, the aircraft track also passed several times through the outflow of the convective system as shown in Fig. 9b and 10b.

\subsubsection{Measurements}

Figure 11 gives a 3-D view of the measured $\mathrm{CO}$ vmr along the flight tracks on the 19 15 November and on the 9 December. Figure 11a shows an enhancement of $\mathrm{CO} \mathrm{vmr}$ when the aircraft flew through the outflow of the convective system. This is identified in the figure as the box labelled [CO] $]_{U T C o n v}$. Lower $\mathrm{CO}$ vmr were recorded outside of the convective system (noted [CO $]_{U T}$ ). Similarly, in Fig. $11 \mathrm{~b}$ there is clearly more CO in the part of the track where the aircraft sampled air in the convective outflow than when it 20 sampled air outside.

Figure 12a-1 and b-1 presents the vmr profiles of $\mathrm{CO}$ and $\mathrm{CH}_{4}$ measured by SPIRIT for these two flights as a function of altitude (between 0 and $5 \mathrm{~km}$ ) and Fig. 12a-2 and $12 \mathrm{~b}-2$ as a function of time for altitudes greater than $7 \mathrm{~km}$. The right panels highlight several periods of time characterized by a significant increase (several ppbv) of $\mathrm{CO}$

directly correlated with a $\mathrm{CH}_{4}$ increase in the upper troposphere. The enhancement of $\mathrm{CH}_{4}$ is more visible for the flight on the 9 December. On the 19 November, an overall increase in $\mathrm{CH}_{4}$ vmr is observable between 8.4 and $9.7 \mathrm{~h}$ UTC with some visible correlations with $\mathrm{CO}$, e.g. at 8.65, 8.9, 9.2, 9.35, 9.55 and $9.65 \mathrm{~h}$. For both flights, the
AMTD

8, 9165-9207, 2015

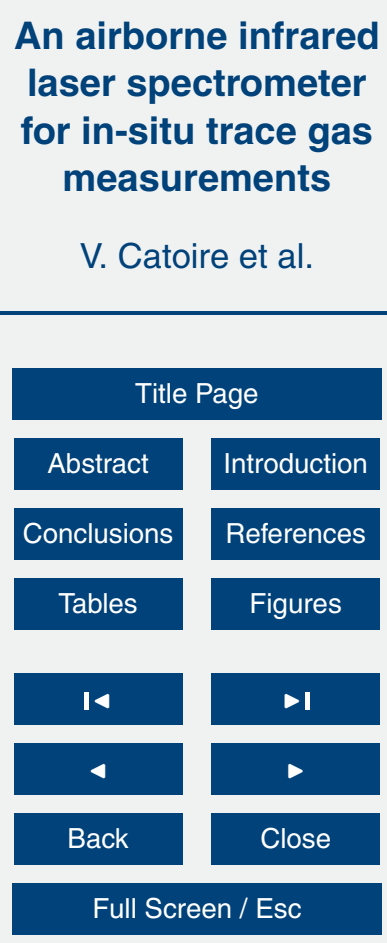

Printer-friendly Version

Interactive Discussion 
peaks in $\mathrm{CO}$ and $\mathrm{CH}_{4} \mathrm{vmr}$ (during a few minutes) correspond to the part of the tracks performed within the convective outflow, and alternating with lower vmr when the aircraft exits the cloud. The onboard webcam images showing the inside and the outside of the cloud were also synchronised with theses variations. $\mathrm{CO}$ and $\mathrm{CH}_{4}$ have emis5 sions sources mainly in the boundary layer and the left panels show much higher vmr in this layer for these two species. The peaks observed in the upper troposphere are indicative of transport of polluted air from the boundary layer to the free troposphere. This suggests a convective transport of $\mathrm{CO}$ and $\mathrm{CH}_{4}$ from the lower troposphere to the upper troposphere. In Fig. 12, the CO vmr in the upper troposphere (8-13 km) without 10 influence of convection has mean values [CO $]_{U T}=75 \pm 2(1 \sigma)$ ppbv and $70 \pm 2(1 \sigma)$ ppbv for the flights on 19 November and 9 December, respectively, with the reported uncertainties representing the standard deviation $(1 \sigma)$ on the mean. Sudden increases above these backgrounds of between 7 and $28 \%$ of the mean [CO] $]_{U T}$ can be observed that directly correlate to the flight path into clouds. This kind of increase (5-20 ppbv) 15 has been also observed in studies by Bechara et al. (2010) and Borbon et al. (2012). It is important to notice that several flights during the SHIVA campaign experienced cloud presence without any significant correlation with $\mathrm{CO}$ enhancement (e.g. the first flight of the day of 19 November and the two flights on 7 December) because these were likely not fresh convective clouds.

\subsection{Fraction of planetary boundary layer (PBL) air detected in the UT}

In order to determine the air fraction $f$ coming from the boundary layer and transported by convective transport, the tracer's vmr $[X]$ is used (Bertram et al., 2007) in Eq. (2):

$[X]_{\text {UTconv }}=f[X]_{\text {surface }}+(1-f) \cdot[X]_{\mathrm{UT}}$

where $[X]_{\text {UTconv }}$ represents the tracer's vmr in the convective outflow. This area is defined as the cloud area where $\mathrm{CO} v \mathrm{vmr}$ is larger than $78 \mathrm{ppbv}$. With this definition, the mean [CO] UTconv are $81 \pm 1(1 \sigma)$ and $83 \pm 3(1 \sigma)$ ppbv for the flights on 19 November and 9 December, respectively. $[X]_{U T}$ has been defined and given just above (Sect. 3.2.2) for

\section{AMTD}

8, 9165-9207, 2015

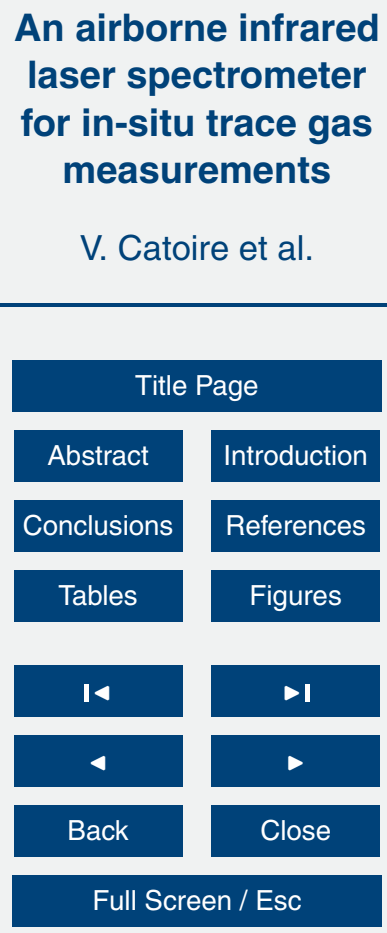

Printer-friendly Version

Interactive Discussion 
$\mathrm{CO}$ and $[X]_{\text {surface }}$ is the tracer vmr in the boundary layer. We assume that the upper limit of the boundary layer is determined by where the $\mathrm{CO}$ and $\mathrm{CH}_{4} \mathrm{vmr}$ start to decrease, $500 \mathrm{~m}$ and $1.2 \mathrm{~km}$ on 19 November and 9 December, respectively. The flight on the 9 December allows the direct measurement of the tracer's vmr in the region just below 5 the convection, as seen in Fig. 11b. [CO $]_{\text {surface }}$ for this flight is on average $130 \pm 5$ ppbv (based on measurements only above $1 \mathrm{~km}$ altitude due to delay in the switch-on of SPIRIT). For the flight on the 19 November, the convective area is situated near Miri in Borneo Island, which is the take-off and landing point (Fig. 11a). Mean [CO $]_{\text {surface }}$ for this flight is $101 \pm 3$ ppbv.

10 We used the same criteria of altitude and timing during the flights for determining the $\mathrm{CH}_{4}$ vmr in the convection, in the upper troposphere and in the boundary layer for both flights as we do for $\mathrm{CO}$. So $\left[\mathrm{CH}_{4}\right]_{\text {UTconv }}$ are $1879 \pm 23 \mathrm{ppbv}$ and $1824 \pm 12 \mathrm{ppbv}$, $\left[\mathrm{CH}_{4}\right]_{\mathrm{UT}}$ are $1871 \pm 19 \mathrm{ppbv}$ and $1808 \pm 10 \mathrm{ppbv}$, and $\left[\mathrm{CH}_{4}\right]_{\text {surface }}$ are $1901 \pm 12 \mathrm{ppbv}$ and $1860 \pm 20$ ppbv for the flights on the 19 November and 9 December, respectively, where 15 the uncertainties are still $1 \sigma$ on the mean. These values are summarized in Table 3.

The deduced fractions $f$ of air injected in the upper troposphere by convection and coming from the boundary layer are $23 \pm 4 \%$ and $22 \pm 5 \%$ (with uncertainties derived from the roots of the quadratic sum of the quoted standard deviations of the measurements) from $\mathrm{CO}$ measurements and $27 \pm 50 \%$ and $31 \pm 24 \%$ from $\mathrm{CH}_{4}$ measurements for the flights on the 19 November and 9 December, respectively. On average, $26 \pm 5 \%$ of air present in the convective area comes from the boundary layer. Table 3 compares these values with the fraction $f$ found in the literature. Our value is in accordance within uncertainties with the values of $17 \%$ of Bertram et al. (2007) and of $20-45 \%$ of Ray et al. (2004) in USA and Mexico gulf, respectively. Like our study, these authors used $\mathrm{CO}$ and $\mathrm{CH}_{4}$ among other tracers to calculate the fraction. However, our value is lower compared to the values referred by Cohan et al. (1999) in the South Pacific or Bechara et al. (2010) in West Africa. The result of Cohan et al. (1999) is a mean value for all the South Pacific $\left(60^{\circ}-10^{\circ} \mathrm{S}\right)$ calculated with the three short-lived species, $\mathrm{CH}_{3} \mathrm{l}, \mathrm{CH}_{3} \mathrm{O}_{2} \mathrm{H}$ and $\mathrm{CHBr}_{3}$. In addition, data available for $\mathrm{CHBr}_{3}$ during SHIVA aircraft campaign from

\section{AMTD}

8, 9165-9207, 2015

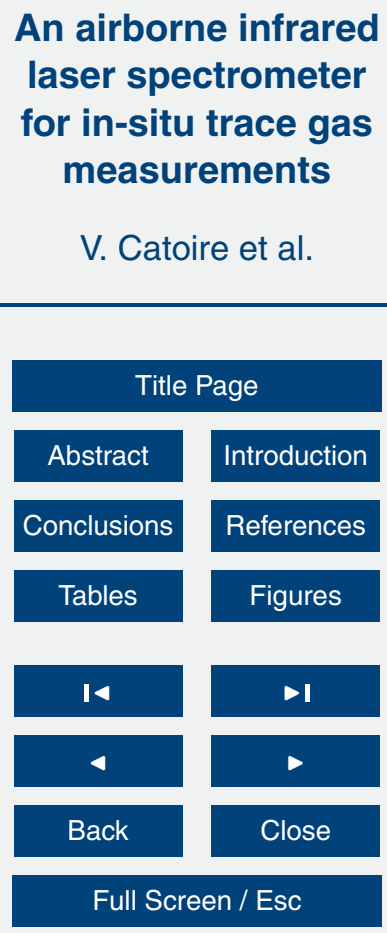

Printer-friendly Version

Interactive Discussion 
the 19 November flight in Hamer et al. (2013) allow a calculation of $f$ ranging from 14 to $29 \%$ (this uncertainty comes from whether the upper or lower boundary layer $\mathrm{CHBr}_{3}$ vmr are used). The upper part of the range is consistent with the values of calculated here for the same flight. However, this kind of calculation is closely dependent on the 5 tracers' lifetime and the presence of sources, which are more variable for $\mathrm{CHBr}_{3}$ than $\mathrm{CO}$ and $\mathrm{CH}_{4}$.

\section{Conclusions}

A three-channel laser absorption spectrometer has been set up for airborne measurements of trace gases. This consists of the coupling of three Quantum Cascade 10 Lasers (CW-DFB-QCLs) with a single Robert multipass optical cell. $\mathrm{CO}, \mathrm{CH}_{4}, \mathrm{~N}_{2} \mathrm{O}$ and $\mathrm{CO}_{2}$ have been measured simultaneously with high time resolution. The instrument achieved $1.6 \mathrm{~s}$ retrieval fitting precision of 1,1 and $3 \%$, and volume mixing ratio sensitivities of $0.4,6$ and 2.4 ppbv for $\mathrm{CO}, \mathrm{CH}_{4}$ and $\mathrm{N}_{2} \mathrm{O}$, respectively (all at $1 \sigma$ confidence level). Estimated accuracies without calibration are about $6 \%$, limited mainly by the 15 accuracy of the molecular spectroscopy database. This error is not large enough to affect the present application where the main interest was devoted to the study of local variation due to transport and chemistry.

The instrument was successfully employed during a large aircraft campaign over Malaysia during November and December 2011. Measurements of $\mathrm{CO}$ and $\mathrm{CH}_{4}$ in the upper troposphere show increases directly correlated with the presence of convective outflow. These measurements during a convective event clearly indicate transport of boundary layer air into the upper troposphere. During this study, CO proved to be a particularly good tracer of this phenomenon and lead to the quantification of the fraction of air originating from ground level. Calculations suggest that air in the convective outflow contains between 20 and $30 \%$ boundary layer air in accordance with the literature.

Since then, SPIRIT has been successfully employed in other projects about greenhouse gases $\left(\mathrm{CH}_{4}, \mathrm{~N}_{2} \mathrm{O}, \mathrm{CO}_{2}\right)$ and pollutants $\left(\mathrm{CO}, \mathrm{O}_{3}\right)$ over the Mediterranean within
AMTD

8, 9165-9207, 2015

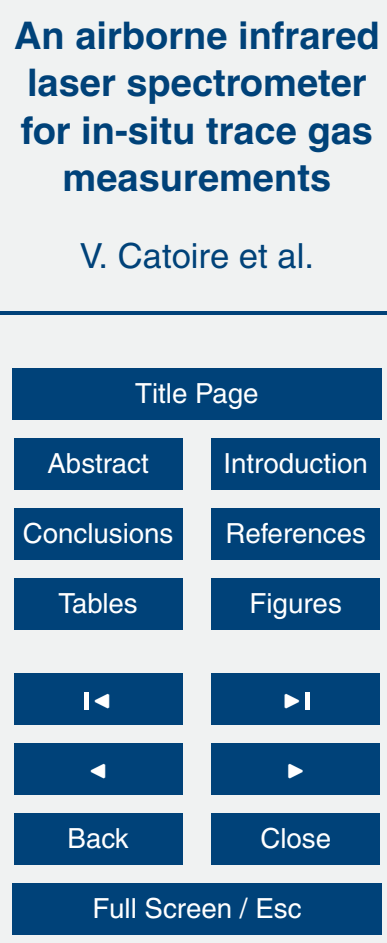

Printer-friendly Version

Interactive Discussion 
the frame of the ChArMEx project (https://charmex.Isce.ipsl.fr/), and about production of nitrogen dioxide $\left(\mathrm{NO}_{2}\right)$ in contrails (http://www.cerfacs.fr/TC2/). Besides the availability of commercial spectrometers, keeping capability in the development of home-made instruments such as the one presented here is valuable in order to master the data 5 retrieval process and the choice of the molecules to quantify as a function of specific scientific objectives. Carbonyl sulphide (OCS), formaldehyde ( $\mathrm{HCHO}$ ) and hydrogen peroxide $\left(\mathrm{H}_{2} \mathrm{O}_{2}\right)$ are molecules to be potentially detected in future projects.

Acknowledgements. The contributions of S. Chevrier, L. Pomathiod, G. Chalumeau and K. Le Letty for engineering and construction of the instrument and for operations during the campaign 10 are very gratefully acknowledged. This study has been possible thanks to funding provided by the EU project SHIVA (FP7-ENV-2007-1-226224) and the Labex Voltaire (ANR-10-LABX-10001). We thank K. Grossmann and K. Pfeilsticker (Uni. Heidelberg, Germany) for making the cloud pictures available and the aircraft pilots from DLR for the very successful flights. We thank X. Faïn (LGGE, Grenoble, France) for lending us the calibrated gas cylinders, SAFIRE (CNRS-INSU and MétéoFrance) and F. Gheusi (LA, Toulouse, France) for making the CO intercomparison at the Pic du Midi de Bigorre possible and the data availaible. The CTOP data were collected and distributed by Research Institute for Sustainable Humanosphere, Kyoto University, Japan (http://database.rish.kyoto-u.ac.jp/index-e.html). J.-P. Olry (SATMOS, "Centre de Météorologie Spatiale", Météo-France, Lannion, France) is acknowledged for making satellite 20 data available.

\section{References}

Bartlett, K. B., Sachse, G. W., Slate, T., Harward, C., and Blake, D. R.: Large-scale distribution of $\mathrm{CH}_{4}$ in the western North Pacific: sources and transport from the Asian continent, J. Geophys. Res., 108, 8807, doi:10.1029/2002JD003076, 2003.

25 Bechara, J., Borbon, A., Jambert, C., Colomb, A., and Perros, P. E.: Evidence of the impact of deep convection on reactive Volatile Organic Compounds in the upper tropical troposphere during the AMMA experiment in West Africa, Atmos. Chem. Phys., 10, 10321-10334, doi:10.5194/acp-10-10321-2010, 2010.

\section{AMTD}

8, 9165-9207, 2015

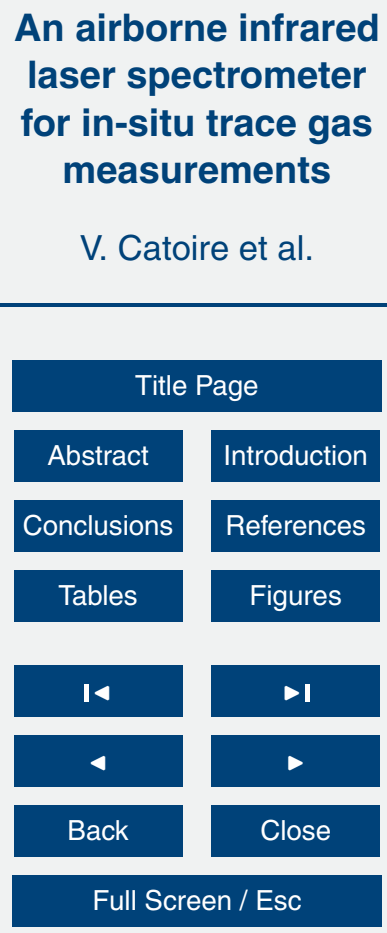

Printer-friendly Version

Interactive Discussion 
Berman, E. S. F., Fladeland, M., Liem, J., Kolyer, R., and Gupta, M.: Greenhouse gas analyser for measurements of carbon dioxide, methane, and water vapor aboard an unmanned aerial vehicle, Sensor Actuat. B-Chem., 169, 128-135, doi:10.1016/j.snb.2012.04.036, 2012.

Bertram, T. H., Perring, A. E., Wooldridge, P. J., Crounse, J. D., Kwan, A. J., Wennberg, P. O., Scheuer, E., Dibb, J., Avery, M., Sachse, G., Vay, S. A., Crawford, J. H., McNaughton, C. S., Clarke, A., Pickering, K. E., Fuelberg, H., Huey, G., Blake, D. R., Singh, H. B., Hall, S. R., Shetter, R. E., Fried, A., Heikes, B. G., and Cohen, R. C.: Direct measurements of the convective recycling of the upper troposphere, Science, 315, 816-820, 2007.

Borbon, A., Ruiz, M., Bechara, J., Aumont, B., Chong, M., Huntrieser, H., Mari, C., Reeves, C. E., Scialom, G., Hamburger, T., Stark, H., Afif, C., Jambert, C., Mills, G., Schlager, H., and Perros, P. E.: Transport and chemistry of formaldehyde by mesoscale convective systems in West Africa during AMMA 2006, J. Geophys. Res., 117, D12301, doi:10.1029/2011JD017121, 2012.

Christensen, L. E., Webster, C. R., and Yang, R. Q.: Aircraft and balloon in situ measurements of 15 methane and hydrochloric acid using interband cascade lasers, Appl. Opt., 46, 1132-1138, 2007.

Cohan, D. S., Schultz, M. G., Jacob, D. J., Heikes, B. G., and Blake, D. R.: Convective injection and photochemical decay of peroxides in the tropical upper troposphere: methyl iodide as a tracer of marine convection, J. Geophys. Res., 104, 5717-5724, 1999.

Curl, R. F., Capasso, F., Gmachl, C., Kosterev, A. A., McManus, B., Lewicki, R., Pusharsky, M., Wysocki, G., and Tittel, F. K.: Quantum cascade lasers in chemical physics, Chem. Phys. Lett., 487, 1-18, 2010.

D'Amato, F., Mazzinghi, P., and Castagnoli, F.: Methane analyzer based on TDL for measurements in the lower stratosphere: design and laboratory tests, Appl. Phys. B, 75, 195-202, 2002.

de Reus, M., Fischer, H., Arnold, F., de Gouw, J., Holzinger, R., Warneke, C, and Williams, J.: On the relationship between acetone and carbon monoxide in different air masses, Atmos. Chem. Phys., 3, 1709-1723, doi:10.5194/acp-3-1709-2003, 2003.

Durry, G., Amarouche, N., Joly, L., Liu, X., Parvitte, B., and Zéninari, V.: Laser diode spectroscopy of $\mathrm{H}_{2} \mathrm{O}$ at $2.63 \mu \mathrm{m}$ for atmospheric applications, Appl. Phys. B, 90, 573-580, doi:10.1007/s00340-007-2884-3, 2007.

Dyroff, C., Zahn, A., Sanati, S., Christner, E., Rauthe-Schöch, A., and Schuck, T. J.: Tunable diode laser in-situ $\mathrm{CH}_{4}$ measurements aboard the CARIBIC passenger aircraft: instrument
AMTD

8, 9165-9207, 2015

\section{An airborne infrared laser spectrometer for in-situ trace gas measurements}

v. Catoire et al.

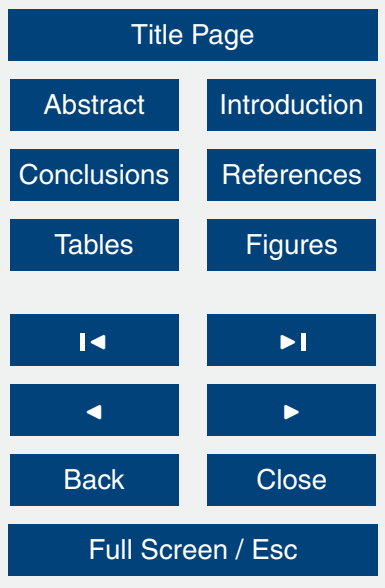

Printer-friendly Version

Interactive Discussion 
performance assessment, Atmos. Meas. Tech., 7, 743-755, doi:10.5194/amt-7-743-2014, 2014.

Dyroff, C., Sanati, S., Christner, E., Zahn, A., Balzer, M., Bouquet, H., McManus, J. B., González-Ramos, Y., and Schneider, M.: Airborne in situ vertical profiling of $\mathrm{HDO} / \mathrm{H}_{2}^{16} \mathrm{O}$ in the subtropical troposphere during the MUSICA remote sensing validation campaign, Atmos. Meas. Tech., 8, 2037-2049, doi:10.5194/amt-8-2037-2015, 2015.

Fried, A. and Richter, D.: Infrared absorption spectroscopy, in: Analytical Techniques for Atmospheric Measurement, edited by: Heard, D., Blackwell Publishing Ltd., Oxford, UK, 72-146, 2006.

10 Fried, A., Wert, B., Henry, B. E., and Drummond, J. R.: Airborne tunable diode laser measurements of formaldehyde, Spectrochim. Acta A-M., 55, 2097-2110, doi:10.1016/S13861425(99)00082-7, 1999.

Fried, A., Wang, Y., Cantrell, C., Wert, B., Walega, W., Ridley, B., Atlas, E., Shetter, R., Lefer, B., Coffey, M.T., Hannigan, J., Blake, D., Blake, N., Meinardi, S., Talbot, B., Dibb, J., Scheuer, E., Wingenter, O., Snow, J., Heikes, B., and Ehhalt, D.: Tunable diode laser measurements of formaldehyde during the TOPSE 2000 study: distributions, trends, and model comparisons, J. Geophys. Res., 108, 8365, doi:10.1029/2002JD002208, 2003.

Gheusi, F., Ravetta, F., Delbarre, H., Tsamalis, C., Chevalier-Rosso, A., Leroy, C., Augustin, P., Delmas, R., Ancellet, G., Athier, G., Bouchou, P., Campistron, B., Cousin, J.M., Fourmentin, M., and Meyerfeld, Y.: Pic 2005, a field campaign to investigate low-tropospheric ozone variability in the Pyrenees, Atmos. Res., 101, 640-665, doi:10.1016/j.atmosres.2011.04.014, 2011.

Gogo, S., Guimbaud, C., Laggoun-Défarge, F., Catoire, V., and Robert, C.: In situ quantification of $\mathrm{CH}_{4}$ bubbling events from a peat soil using a new infrared laser spectrometer, J. Soils Sediments, 11, 545-551, doi:10.1007/s11368-011-0338-3, 2011.

Guimbaud, C., Catoire, V., Gogo, S., Robert, C., Laggoun-Défarge, F., Chartier, M., Grossel, A., Albéric, P., Pomathiod, L., Nicoullaud, B., and Richard, G.: A portable infrared laser spectrometer for flux measurements of trace gases at the geosphere-atmosphere interface, Meas. Sci. Technol., 22, 075601, doi:10.1088/0957-0233/22/7/075601, 2011.

30 Hamada, A. and Nishi, N.: Development of a cloud-top height estimation method by geostationary satellite split-window measurements trained with CloudSat data, J. Appl. Meteor. Climate, 49, 2035-2049, 2010.
AMTD

8, 9165-9207, 2015

\section{An airborne infrared laser spectrometer for in-situ trace gas measurements}

V. Catoire et al.

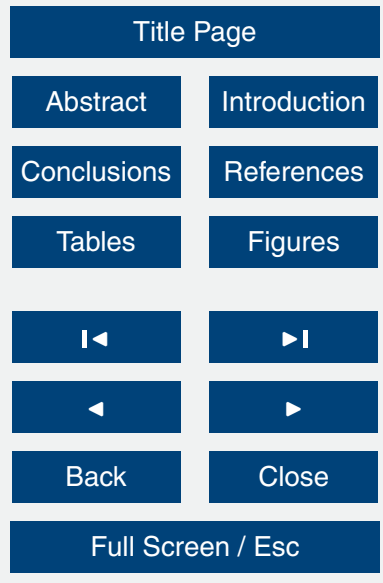

Printer-friendly Version

Interactive Discussion 
Hamer, P. D., Marécal, V., Hossaini, R., Pirre, M., Warwick, N., Chipperfield, M., Samah, A. A., Harris, N., Robinson, A., Quack, B., Engel, A., Krüger, K., Atlas, E., Subramaniam, K., Oram, D., Leedham, E., Mills, G., Pfeilsticker, K., Sala, S., Keber, T., Bönisch, H., Peng, L. K., Nadzir, M. S. M., Lim, P. T., Mujahid, A., Anton, A., Schlager, H., Catoire, V., Krysztofiak, G., Fühlbrügge, S., Dorf, M., and Sturges, W. T.: Modelling the chemistry and transport of bromoform within a sea breeze driven convective system during the SHIVA Campaign, Atmos. Chem. Phys. Discuss., 13, 20611-20676, doi:10.5194/acpd-13-20611-2013, 2013.

Herndon, S. C., Zahniser, M. S., Nelson Jr., D. D., Shorter, J., McManus, J. B., Jimenez, R., Warneke, C., and de Gouw, J. A.: Airborne measurements of $\mathrm{HCHO}$ and $\mathrm{HCOOH}$ during the New England Air Quality Study 2004 using a pulsed quantum cascade laser spectrometer, J. Geophys. Res., 112, D10S03, doi:10.1029/2006JD007600, 2007.

Iwasaki, S., Shibata, T., Nakamoto, J., Okamoto, H., Ishimoto, H., and Kubota, H.: Characteristics of deep convection measured by using the A-train constellation, J. Geophys. Res., 115, D06207, doi:10.1029/2009JD013000, 2010.

Kerstel, E. R. T., lannone, R. Q., Chenevier, M., Kassi, S., Jost, H.-J., and Romanini, D.: A water isotope $\left({ }^{2} \mathrm{H},{ }^{17} \mathrm{O}\right.$, and $\left.{ }^{18} \mathrm{O}\right)$ spectrometer based on optical feedback cavity-enhanced absorption for in situ airborne applications, Appl. Phys. B, 85, 397-406, 2006.

Kormann, R., Fischer, H., de Reus, M., Lawrence, M., Brühl, Ch., von Kuhlmann, R., Holzinger, R., Williams, J., Lelieveld, J., Warneke, C., de Gouw, J., Heland, J., Ziereis, H., and Schlager, $\mathrm{H}$.: Formaldehyde over the eastern Mediterranean during MINOS: Comparison of airborne in-situ measurements with 3D-model results, Atmos. Chem. Phys., 3, 851-861, doi:10.5194/acp-3-851-2003, 2003.

Kort, E. A., Patra, P. K., Ishijima, K., Daube, B. C., Jiménez, R., Elkins, J., Hurst, D., Moore, F. L., Sweeney, C., and Wofsy, S. C.: Tropospheric distribution and variability of N2O: evidence for strong tropical emissions, Geophys. Res. Lett., 38, L15806, doi:10.1029/2011GL047612, 2011.

Lopez, J. P., Luo, M., Christensen, L. E., Loewenstein, M., Jost, H., Webster, C. R., and Osterman, G.: TES carbon monoxide validation during two AVE campaigns using the Argus and ALIAS instruments on NASA's WB-57F, J. Geophys. Res., 113, D16S47, doi:10.1029/2007JD008811, 2008.

Marandino, C. A., Tegtmeier, S., Krüger, K., Zindler, C., Atlas, E. L., Moore, F., and Bange, H. W.: Dimethylsulphide (DMS) emissions from the western Pacific Ocean: a potential marine
AMTD

8, 9165-9207, 2015

\section{An airborne infrared laser spectrometer for in-situ trace gas measurements}

V. Catoire et al.

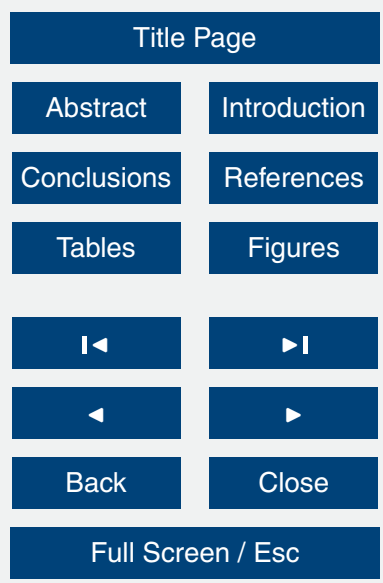

Printer-friendly Version

Interactive Discussion 
source for stratospheric sulphur?, Atmos. Chem. Phys., 13, 8427-8437, doi:10.5194/acp13-8427-2013, 2013.

McManus, J. B., Nelson, D. D., Shorter, J. H., Jimenez, R., Herndon, S., Saleska, S., and Zahniser, M.: A high precision pulsed quantum cascade laser spectrometer for measurements of stable isotopes of carbon dioxide, J. Mod. Opt., 52, 2309-2321, 2005.

McManus, J. B., Zahniser, M. S., and Nelson, D. D.: Dual quantum cascade laser trace gas instrument with astigmatic Herriott cell at high pass number, Appl. Optics, 50, A74-A85, 2011.

McQuaid, J., Schlager, H., Andrés-Hernández, M. D., Ball, S., Borbon, A., Brown, S. S., Catoire, V., Di Carlo, P., Custer, T. G., von Hobe, M., Hopkins, J., Pfeilsticker, K., Röckmann, T., Roiger, A., Stroh, F., Williams, J., and Ziereis, H.: Chapter 3: In situ trace gas measurements, in: Airborne Measurements: Methods and Instruments, edited by: Wendisch, M. and Brenguier, J.-L., EUFAR Wiley-VCH, Weinheim (Germany), 104-107, 2013.

Moreau, G., Robert, C., Catoire, V., Chartier, M., Camy-Peyret, C., Huret, N., Pirre, M., Pomath15 iod, L., and Chalumeau, G.: SPIRALE: a multispecies in situ balloon-borne experiment with six tunable diode laser spectrometers, Appl. Optics, 44, 5972-5989, 2005.

Neuman, J. A., Huey, L. G., Ryerson, T. B., and Fahey, D. W.: Study of inlet materials for sampling atmospheric nitric acid, Environ. Sci. Technol., 33, 1133-1136, 1999.

Podolske, J. R., Sachse, G. W., and Diskin, G. S.: Calibration and data retrieval algorithms for the NASA Langley/Ames Diode Laser Hygrometer for the NASA transport and chemical evolution over the Pacific (TRACE-P) mission, J. Geophys. Res., 108, 8792, doi:10.1029/2002JD003156, 2003.

Ray, E. A., Rosenlof, K. H., Richard, E. C., Hudson, P. K., Cziczo, D. J., Loewenstein, M., Jost, H.-J., Lopez, J., Ridley, B., Weinheimer, A., Montzka, D., Knapp, D., Wofsy, S. C., Daube, B. C., Gerbig, C., Xueref, I., and Herman, R. L.: Evidence of the effect of summertime midlatitude convection on the subtropical lower stratosphere from CRYSTAL-FACE tracer measurements, J. Geophys. Res., 109, D18304, doi:10.1029/2004JD004655, 2004.

Robert, C.: Simple, stable, and compact multiple-reflection optical cell for very long optical paths, Appl. Optics, 46, 5408-5418, 2007.

so Rollins, A. W., Thornberry, T. D., Gao, R. S., Smith, J. B., Sayres, D. S., Sargent, M. R., Schiller, C., Krämer, M., Spelten, N., Hurst, D. F., Jordan, A. F., Hall, E. G., Vömel, H., Diskin, G. S., Podolske, J. R., Christensen, L. E., Rosenlof, K. H., Jensen, E. J., and Fahey, D. W.:
AMTD

8, 9165-9207, 2015

\section{An airborne infrared laser spectrometer for in-situ trace gas measurements}

V. Catoire et al.

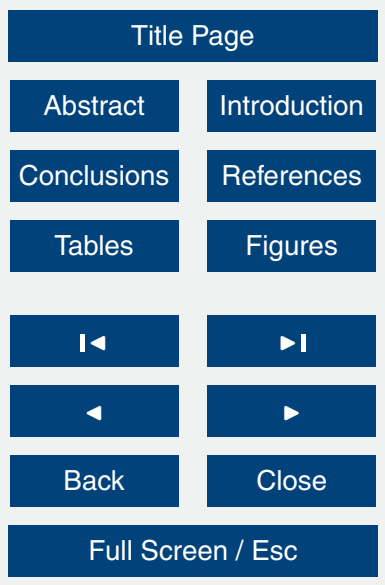

Printer-friendly Version

Interactive Discussion 
Evaluation of UT/LS hygrometer accuracy by intercomparison during the NASA MACPEX mission, J. Geophys. Res. Atmos., 119, 1915-1935, doi:10.1002/2013JD020817, 2014.

Rothman, L. S., Gordon, I. E., Babikov, Y., Barbe, A., Benner, D. C., Bernath, P. F., Birk, M., Bizzocchi, L., Boudon, V., Brown, L. R., Campargue, A., Chance, K., Cohen, E. A., Coudert, L. H., Devi, V. M., Drouin, B. J., Fayt, A., Flaud, J.-M., Gamache, R. R., Harrison, J. J., Hartmann, J.-M., Hill, C., Hodges, J. T., Jacquemart, D., Jolly, A., Lamouroux, J., LeRoy, R. J., Li, G., Long, D. A., Lyulin, O. M., Mackie, C. J., Massie, S. T., Mikhailenko, S., Müller, H. S. P., Naumenko, O. V., Nikitin, A. V., Orphal J., Perevalov, V., Perrin, A., Polovtseva, E. R., Richard, C., Smith, M. A. H., Starikova, E., Sung, K., Tashkun, S., Tennyson, J., Toon, G. C., Tyuterev, V. G., and Wagner, G.: The HITRAN2012 molecular spectroscopic database, J. Quant. Spectrosc. Radiat. Transfer, 130, 4-50, 2013.

Santoni, G. W., Daube, B. C., Kort, E. A., Jiménez, R., Park, S., Pittman, J. V., Gottlieb, E., Xiang, B., Zahniser, M. S., Nelson, D. D., McManus, J. B., Peischl, J., Ryerson, T. B., Holloway, J. S., Andrews, A. E., Sweeney, C., Hall, B., Hintsa, E. J., Moore, F. L., Elkins, J. W., Hurst, D. F., Stephens, B. B., Bent, J., and Wofsy, S. C.: Evaluation of the airborne quantum cascade laser spectrometer (QCLS) measurements of the carbon and greenhouse gas suite $-\mathrm{CO}_{2}, \mathrm{CH}_{4}, \mathrm{~N}_{2} \mathrm{O}$, and $\mathrm{CO}$ - during the CalNex and HIPPO campaigns, Atmos. Meas. Tech., 7, 1509-1526, doi:10.5194/amt-7-1509-2014, 2014.

Scott, D. C., Herman, R. L., Webster, C. R., May, R. D., Flesch, G. J., and Moyer, E. J.: Airborne Laser Infrared Absorption Spectrometer (ALIAS-II) for in situ atmospheric measurements of $\mathrm{N}_{2} \mathrm{O}, \mathrm{CH}_{4}, \mathrm{CO}, \mathrm{HCl}$, and $\mathrm{NO}_{2}$ from balloon or remotely piloted aircraft platforms, Appl. Optics, 38, 4609-4622, 1999.

Spiers, G. D., Menzies, R. T., Jacob, J., Christensen, L. E., Phillips, M. W., Choi, Y. H., and Browell, E. V.: Atmospheric $\mathrm{CO}_{2}$ measurements with a $2 \mu \mathrm{m}$ airborne laser absorption spectrometer employing coherent detection, Appl. Opt., 50, 2098-2111, doi:10.1364/AO.50.002098, 2011.

Tegtmeier, S., Krüger, K., Quack, B., Atlas, E., Blake, D. R., Boenisch, H., Engel, A., Hepach, H., Hossaini, R., Navarro, M. A., Raimund, S., Sala, S., Shi, Q., and Ziska, F.: The contribution of oceanic methyl iodide to stratospheric iodine, Atmos. Chem. Phys., 13, 11869-11886, doi:10.5194/acp-13-11869-2013, 2013.

Viciani, S., D’Amato, F., Mazzinghi, P., Castagnoli, F., Toci, G., and Werle, P.: A cryogenically operated laser diode spectrometer for airborne measurement of stratospheric trace gases, Appl. Phys. B, 90, 581-592, doi:10.1007/s00340-007-2885-2, 2008.
AMTD

8, 9165-9207, 2015

\section{An airborne infrared laser spectrometer for in-situ trace gas measurements}

V. Catoire et al.

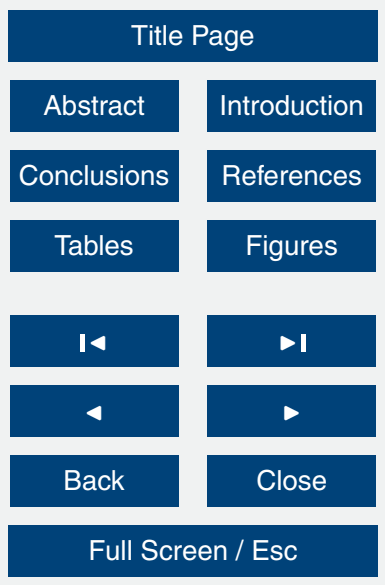

Printer-friendly Version

Interactive Discussion 
Wecht, K. J., Jacob, D. J., Wofsy, S. C., Kort, E. A., Worden, J. R., Kulawik, S. S., Henze, D. K., Kopacz, M., and Payne, V. H.: Validation of TES methane with HIPPO aircraft observations: implications for inverse modeling of methane sources, Atmos. Chem. Phys., 12, 1823-1832, doi:10.5194/acp-12-1823-2012, 2012.

5 Wert, B. P., Fried, A., Rauenbuehler, S., Walega, J., and Henry, B.: Design and performance of a tunable diode laser absorption spectrometer for airborne formaldehyde measurements, $\mathrm{J}$. Geophys. Res., 108, 4350, doi:10.1029/2002JD002872, 2003.

Wienhold, F. G., Fischer, H., Hoor, P., Wagner, V., Königstedt, R., Harris, G., W., Anders, J., Grisar, R., Knothe, M., Riedel, W. J., Lübken, F.-J., and Schilling, T.: TRISTAR - a tracer in situ TDLAS for atmospheric research, Appl. Phys. B, 67, 411-417, doi:10.1007/s003400050524, 1998.

Yacovitch, T. I., Herndon, S. C., Roscioli, J. R., Floerchinger, C., McGovern, R. M., Agnese, M., Pétron, G., Kofler, J., Sweeney, C., Karion, A., Conley, S. A., Kort, E. A., Nähle, L., Fischer, M., Hildebrandt, L., Koeth, J., McManus, J. B., Nelson, D. D., Zahniser, M. S. and Kolb, C. E.: Demonstration of an ethane spectrometer for methane source identification, Environ. Sci. Technol., 48, 8028-8034, 2014.

Zondlo, M. A., Paige, M. E., Massick, S. M., and Silver, J. A.: Vertical cavity laser hygrometer for the National Science Foundation Gulfstream-V aircraft, J. Geophys. Res., 115, D20309, doi:10.1029/2010JD014445, 2010.

\section{AMTD}

8, 9165-9207, 2015

\section{An airborne infrared laser spectrometer for in-situ trace gas measurements}

V. Catoire et al.

Title Page

Abstract Introduction

Conclusions References

Tables Figures

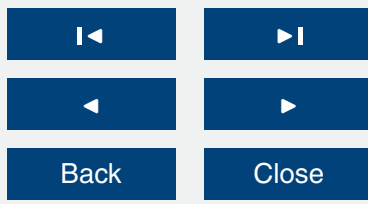

Full Screen / Esc

Printer-friendly Version

Interactive Discussion 
AMTD

8, 9165-9207, 2015

\section{An airborne infrared laser spectrometer for in-situ trace gas measurements}

V. Catoire et al.

Table 1. Spectral domains and condition emissions of QCLs.

\begin{tabular}{lccc}
\hline Molecule & $\begin{array}{c}\text { Spectral } \\
\text { domain }\left(\mathrm{cm}^{-1}\right)\end{array}$ & $\begin{array}{c}\text { Current }+ \\
\text { ramp }(\mathrm{mA})\end{array}$ & $\begin{array}{c}T\left({ }^{\circ} \mathrm{C}\right) \text { of } \\
\text { the QCL }\end{array}$ \\
\hline $\mathrm{CO}$ & $2179.6-2179.9$ & $590+20$ & -12.5 \\
$\mathrm{CH}_{4}, \mathrm{~N}_{2} \mathrm{O}$ & $1249.4-1249.9$ & $490+23$ & +16.8 \\
$\mathrm{CO}_{2}$ & $2064.2-2064.7$ & $565+50$ & -20.5 \\
\hline
\end{tabular}

Title Page

Abstract

Introduction

Conclusions

References

Tables

Figures

14

4

Back

Full Screen / Esc

Printer-friendly Version

Interactive Discussion 
Table 2. Performance characteristics for $\mathrm{CO}, \mathrm{CH}_{4}$ and $\mathrm{N}_{2} \mathrm{O}$ volume mixing ratio measurements (vmr). Sensitivities and relative accuracies are given for vmr close to typical atmospheric levels (100 ppbv CO, 1.8 ppmv $\mathrm{CH}_{4}$ and 325 ppbv $\mathrm{N}_{2} \mathrm{O}$ ).

\begin{tabular}{|c|c|c|c|c|c|c|c|}
\hline \multirow[t]{2}{*}{$\begin{array}{l}\text { Mole- } \\
\text { cule }\end{array}$} & \multirow[t]{2}{*}{$\begin{array}{l}1.6 \mathrm{~s} \text { fitting } \\
\text { precision in } \\
\text { flight }\end{array}$} & \multirow[t]{2}{*}{$\begin{array}{l}\text { Lower } \\
\text { limit of } \\
\text { detection }\end{array}$} & \multicolumn{3}{|c|}{$\begin{array}{c}\text { Sensitivity: } 1 \sigma_{\mathrm{A}} \text { Allan } \\
\text { deviation (ppbv) at three } \\
\text { different averaging times }\end{array}$} & \multirow{2}{*}{$\begin{array}{l}\text { Estimated } \\
\text { accuracies } \\
\text { without } \\
\text { calibration }\end{array}$} & \multirow{2}{*}{$\begin{array}{l}\text { Calculated } \\
\text { accuracies } \\
\text { after } \\
\text { calibration }\end{array}$} \\
\hline & & & $1.6 \mathrm{~s}$ & $10 \mathrm{~s}$ & $100 \mathrm{~s}$ & & \\
\hline $\mathrm{CO}$ & $\begin{array}{c}1 \mathrm{ppbv} \\
(1 \%)\end{array}$ & 0.6 ppbv & 0.4 & 0.22 & 0.13 & $5.7 \%$ & $\begin{array}{c}0.9 \mathrm{ppbv} \\
(0.9 \%)\end{array}$ \\
\hline $\mathrm{CH}_{4}$ & $\begin{array}{c}18 \mathrm{ppbv} \\
(1 \%)\end{array}$ & $9.0 \mathrm{ppbv}$ & 6.0 & 4.0 & 1.3 & $5.7 \%$ & $\begin{array}{c}8.6 \mathrm{ppbv} \\
(0.5 \%)\end{array}$ \\
\hline $\mathrm{N}_{2} \mathrm{O}$ & $\begin{array}{c}10 \mathrm{ppbv} \\
(3 \%)\end{array}$ & $5.3 \mathrm{ppbv}$ & 2.4 & 2.0 & 0.8 & $6.4 \%$ & $\begin{array}{c}3.8 \mathrm{ppbv} \\
(1.2 \%)\end{array}$ \\
\hline
\end{tabular}

AMTD

8, 9165-9207, 2015

An airborne infrared laser spectrometer for in-situ trace gas measurements

V. Catoire et al.

Title Page

Abstract

Introduction

Conclusions

References

Tables

Figures

14

4

Back

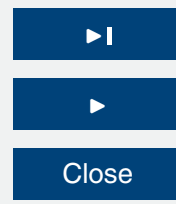

Full Screen / Esc

Printer-friendly Version

Interactive Discussion 
Table 3. Mean mixing ratios for the boundary layer $\left([X]_{\text {surface }}\right)$, upper troposphere $\left([X]_{U T}\right)$ and convective air masses ([X] $]_{\text {UTconv }}$ ) for $\mathrm{CO}$ and $\mathrm{CH}_{4}$ measured by the SPIRIT instrument during the flight on the 19 November and 9 December 2011. These vmr are used in the calculation of the fraction $f$ of air coming from the boundary layer detected in the convective air mass. The mean fraction $f$ found is compared with other convective case studies.

\begin{tabular}{|c|c|c|c|c|c|c|c|}
\hline & & & $\begin{array}{c}{[X]_{\text {surface }}} \\
(\mathrm{ppbv})\end{array}$ & $\begin{array}{l}X]_{\mathrm{UT}} \\
(\mathrm{ppbv})\end{array}$ & $\begin{array}{c}{[X]_{\text {UT conv }}} \\
(\mathrm{ppbv})\end{array}$ & Fraction $f^{1}$ & Comment \\
\hline \multirow[t]{3}{*}{ This study } & 19 Nov & $\begin{array}{l}\mathrm{CO} \\
\mathrm{CH}_{4}\end{array}$ & $\begin{array}{c}101 \\
1901\end{array}$ & $\begin{array}{c}75 \\
1871\end{array}$ & $\begin{array}{c}81 \\
1879\end{array}$ & $\begin{array}{l}0.23 \pm 0.04 \\
0.27 \pm 0.50\end{array}$ & \multirow{3}{*}{$\begin{array}{l}\text { Borneo } \\
\text { region } \\
\left(6^{\circ} \mathrm{N}-117^{\circ} \mathrm{E}\right)\end{array}$} \\
\hline & $9 \mathrm{Dec}$ & $\begin{array}{l}\mathrm{CO} \\
\mathrm{CH}_{4} \\
\end{array}$ & $\begin{array}{c}130 \\
1860 \\
\end{array}$ & $\begin{array}{c}70 \\
1808 \\
\end{array}$ & $\begin{array}{c}83 \\
1824 \\
\end{array}$ & $\begin{array}{l}0.22 \pm 0.05 \\
0.31 \pm 0.24\end{array}$ & \\
\hline & Mean & & & & & $0.26 \pm 0.05$ & \\
\hline $\begin{array}{l}\text { Cohan et al. } \\
\text { (1999) }\end{array}$ & & & & & & $0.36-0.68$ & $\begin{array}{l}\text { South Pacific } \\
\left(60^{\circ} \mathrm{S}-10^{\circ} \mathrm{N}\right)\end{array}$ \\
\hline $\begin{array}{l}\text { Ray et al. } \\
\text { (2004) }\end{array}$ & & & & & & $0.20-0.45$ & $\begin{array}{l}\text { Mexico gulf } \\
\left(20^{\circ} \mathrm{N}\right)\end{array}$ \\
\hline $\begin{array}{l}\text { Bertram et } \\
\text { al. }(2007)\end{array}$ & & & & & & $0.17 \pm 0.08$ & $\begin{array}{l}\text { East USA } \\
\text { and Canada }\end{array}$ \\
\hline $\begin{array}{l}\text { Bechara et } \\
\text { al. (2010) }\end{array}$ & & & & & & $0.40 \pm 0.15$ & West Africa \\
\hline
\end{tabular}

${ }^{1}$ Uncertainties are $1 \sigma$ on the mean.
AMTD

8, 9165-9207, 2015

\section{An airborne infrared laser spectrometer for in-situ trace gas measurements}

V. Catoire et al.

Title Page

Abstract Introduction

Conclusions References

Tables

Figures

\section{4}

4

Back

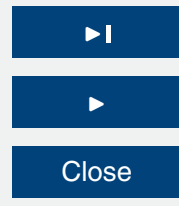

Full Screen / Esc

Printer-friendly Version

Interactive Discussion 


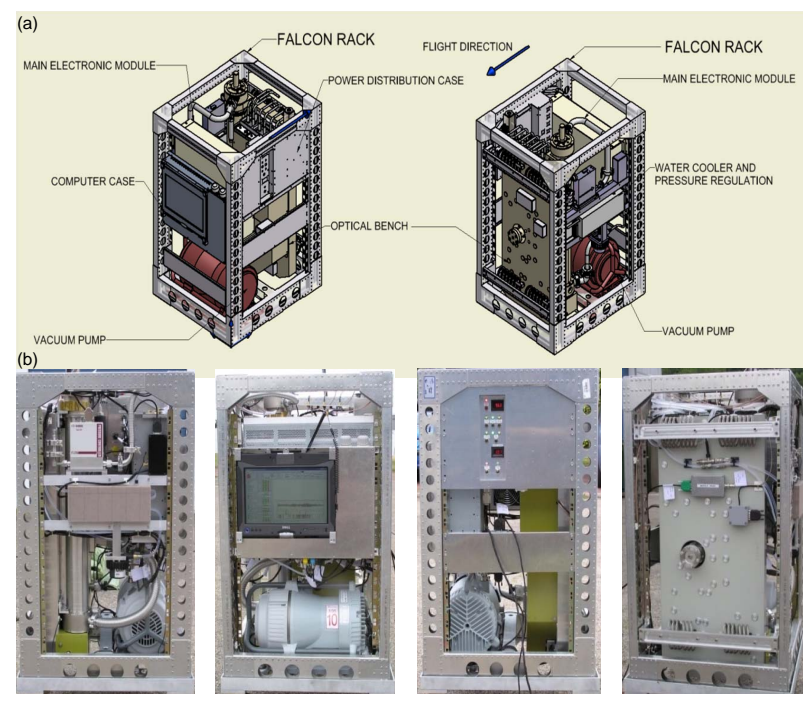

Figure 1. (a) Sketch of the SPIRIT instrument and (b) photographs of its four faces integrated in the Falcon-20 rack.
AMTD

8, 9165-9207, 2015

An airborne infrared laser spectrometer for in-situ trace gas measurements

V. Catoire et al.

\section{Title Page}

Abstract

Introduction

Conclusions

References

Tables

Figures

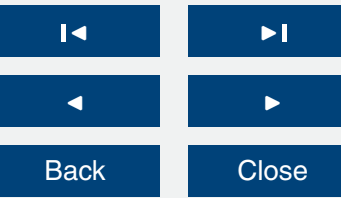

Full Screen / Esc

Printer-friendly Version

Interactive Discussion 
AMTD

8, 9165-9207, 2015

An airborne infrared laser spectrometer for in-situ trace gas measurements

V. Catoire et al.

\section{Title Page}

Abstract

Introduction

Conclusions

References

Tables

Figures

14

$\checkmark$

Back

Close

Full Screen / Esc

Printer-friendly Version

Interactive Discussion 


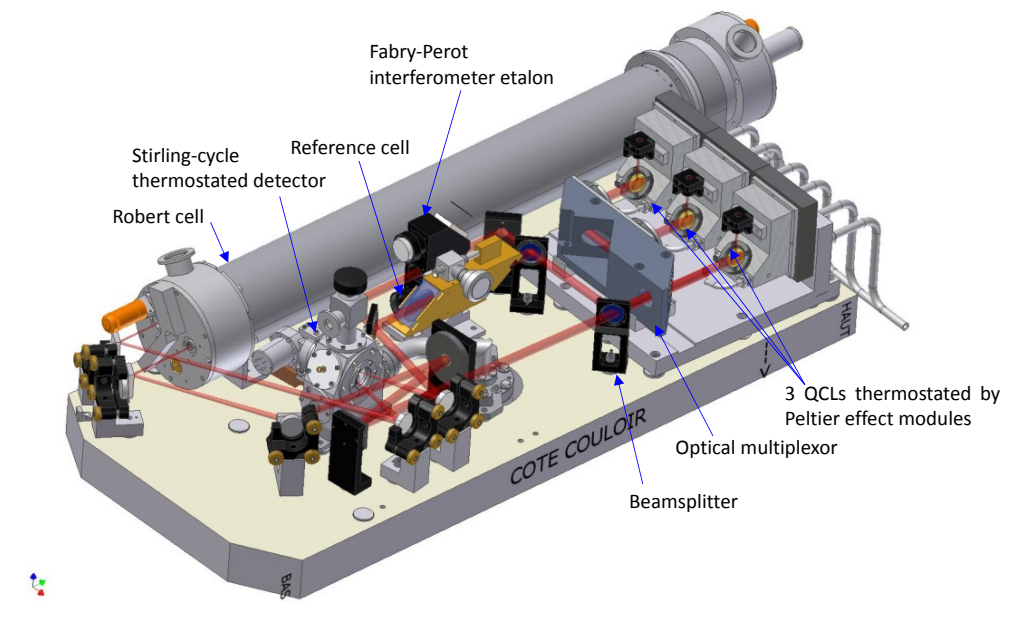

Figure 3. Three-dimensional representation of the optical bench with red rays symbolizing the laser beam paths.

\section{AMTD}

8, 9165-9207, 2015

\section{An airborne infrared laser spectrometer for in-situ trace gas measurements}

V. Catoire et al.

\section{Title Page}

Abstract

Introduction

Conclusions

References

Tables

Figures

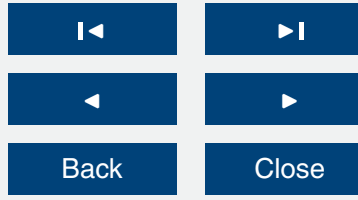

Full Screen / Esc

Printer-friendly Version

Interactive Discussion 


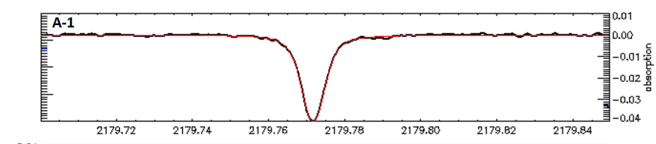

AMTD
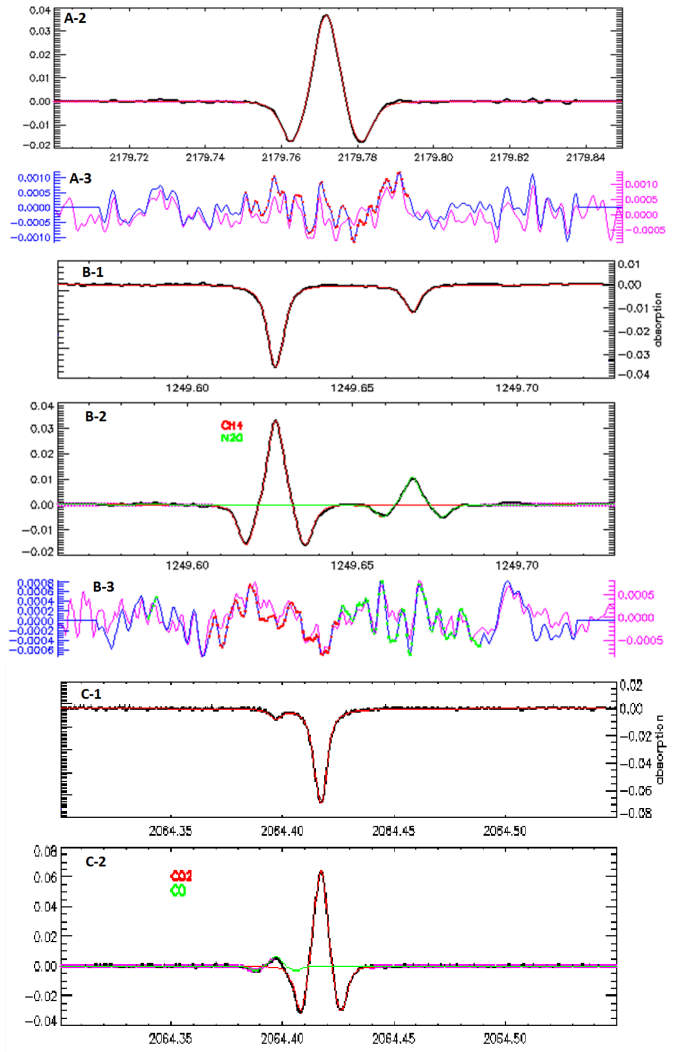

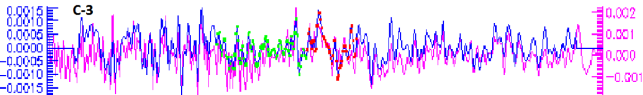

Printer-friendly Version

Interactive Discussion

An airborne infrared laser spectrometer for in-situ trace gas measurements

V. Catoire et al.

\section{Title Page}

Abstract

Introduction

Conclusions

References

Tables

Figures

14

Back

Full Screen / Esc

(c) (1) 
Figure 4. (a) (1): Example of experimental (black line) and simulated (red line) transmission spectrum for $\mathrm{CO}\left(\widetilde{v}_{0}=2179.772 \mathrm{~cm}^{-1}\right)$ recorded on 9 December $2011(9.677 \mathrm{~h} \mathrm{UTC})$ at $12262 \mathrm{~m}$ altitude, $5.45^{\circ} \mathrm{N}-118.92^{\circ} \mathrm{E}$. (2): Experimental (black line) and simulated (red line) second derivatives of this transmission signal. (3): Associated residuals of the direct transmission (pink line) and of the second derivative (blue line), leading to $1 \sigma$ statistical error of $1.3 \%$ on the fit for this latter. This retrieved volume mixing ratio (vmr) is $89.7 \pm 1.3 \mathrm{ppbv}(1 \sigma)$. The cell was at $32.04 \mathrm{hPa}$ pressure and $31.7^{\circ} \mathrm{C}$ temperature, with an optical path of $134.22 \mathrm{~m}$. (b) Same as (a) but for $\mathrm{CH}_{4}$ (red simulated profile centred at $\widetilde{v}_{0}=1249.627 \mathrm{~cm}^{-1}$ ) and $\mathrm{N}_{2} \mathrm{O}$ (green profile at $\widetilde{v}_{0}=1249.668 \mathrm{~cm}^{-1}$ ). This retrieval led to $\mathrm{vmr}$ of $1830 \pm 18 \mathrm{ppbv}$ for $\mathrm{CH}_{4}(1 \sigma=1.0 \%)$ and $320.4 \pm 10.3$ ppbv for $\mathrm{N}_{2} \mathrm{O}(1 \sigma=3.2 \%)$. (c) Same as (a) but for $\mathrm{CO}_{2}$ (red simulated profile centred at $\widetilde{v}_{0}=2064.417 \mathrm{~cm}^{-1}$ ) on the 8 November 2011 (during a transfer flight to Malaysia). This retrieval led to a vmr of $390.2 \pm 2.8 \mathrm{ppmv}(1 \sigma=0.7 \%)$. The small line at $\widetilde{v}_{0}=2064.397 \mathrm{~cm}^{-1}$ is due to $\mathrm{CO}$ absorption and is taken into account for the retrieval, with $\mathrm{CO}$ vmr in good agreement $(<10 \%)$ with that deduced on channel $\mathrm{A}$.

\section{AMTD}

\section{8, 9165-9207, 2015}

\section{An airborne infrared laser spectrometer for in-situ trace gas measurements}

V. Catoire et al.

Title Page

Abstract Introduction

Conclusions

References

Tables

Figures

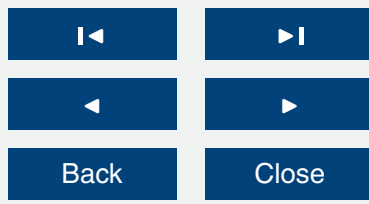

Full Screen / Esc

Printer-friendly Version

Interactive Discussion 


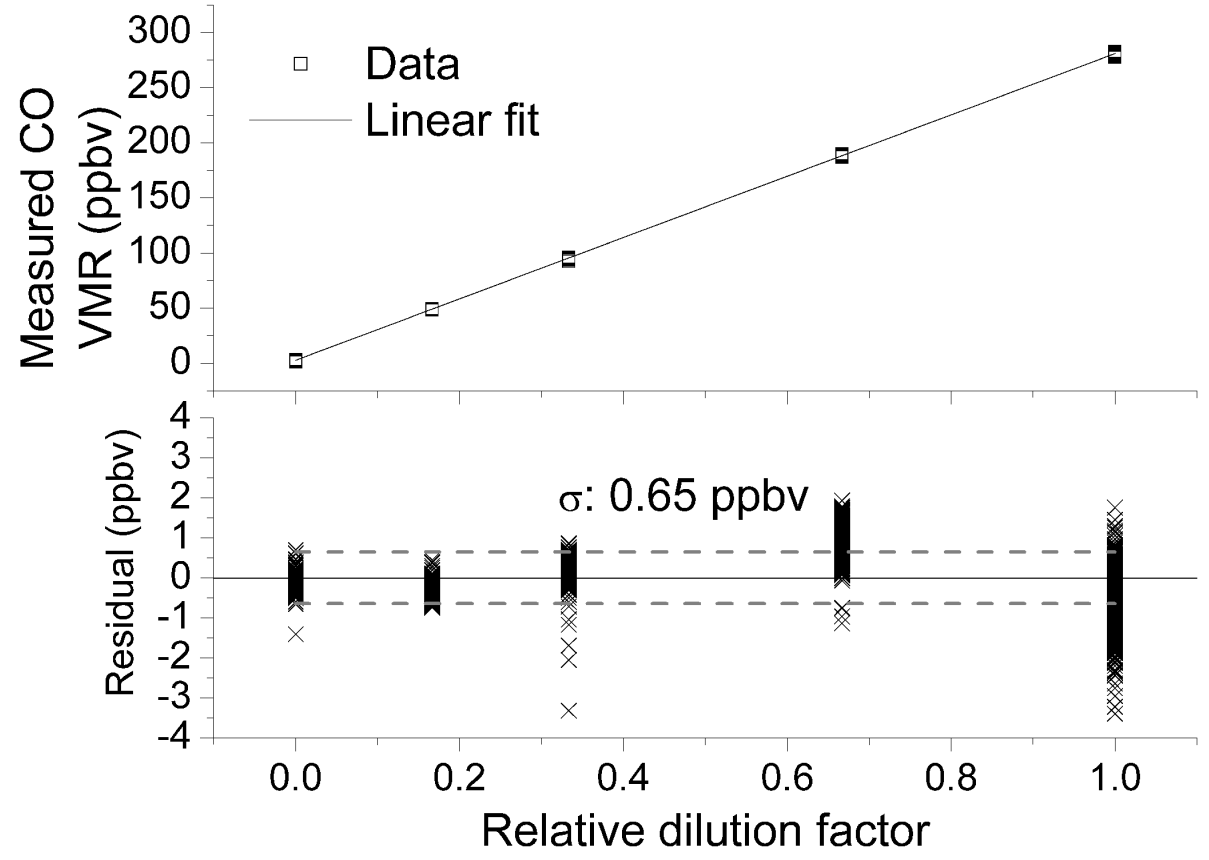

Figure 5. Illustration of linearity of the measurements for $\mathrm{CO}$. Residuals come from subtracting linear fit to data points. Residuals spread around linear fit with one standard deviation $1 \sigma=$ $0.65 \mathrm{ppbv}$ for 3500 separate data.
AMTD

8, 9165-9207, 2015

An airborne infrared laser spectrometer for in-situ trace gas measurements

V. Catoire et al.

Title Page

Abstract

Introduction

Conclusions

References

Tables

Figures

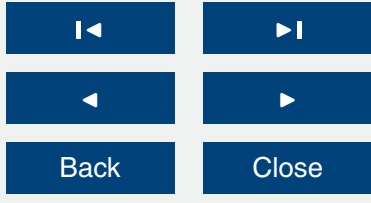

Full Screen / Esc

Printer-friendly Version

Interactive Discussion 


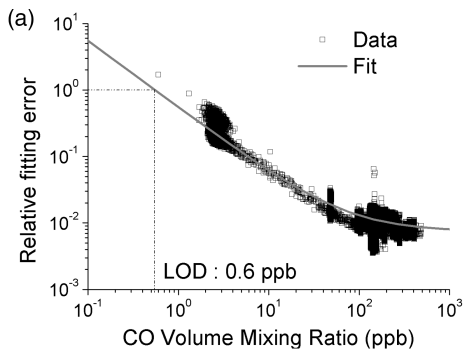

AMTD

8, 9165-9207, 2015

An airborne infrared laser spectrometer for in-situ trace gas measurements

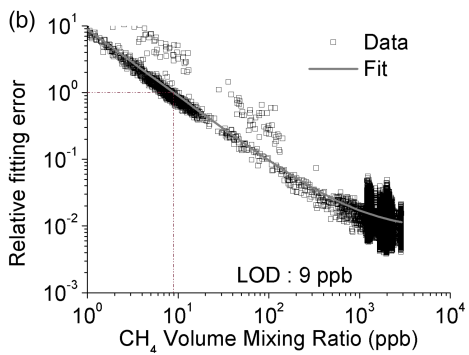

V. Catoire et al.

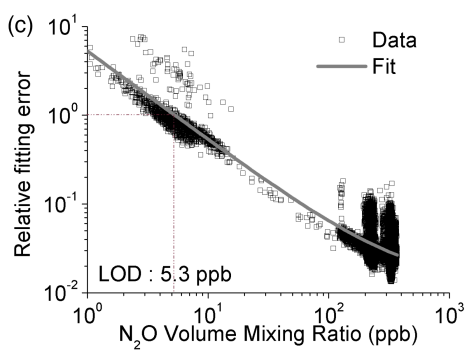

Title Page

Abstract

Introduction

Conclusions

References

Tables

Figures

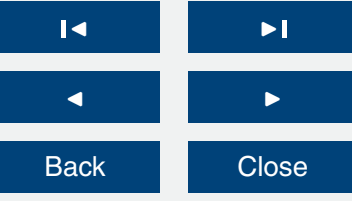

Full Screen / Esc

Figure 6. Relative errors on line fittings leading to the total volume mixing ratios (vmr) of $\mathrm{CO}$ (a), $\mathrm{CH}_{4}$ (b) and $\mathrm{N}_{2} \mathrm{O}$ (c).

Printer-friendly Version

Interactive Discussion 


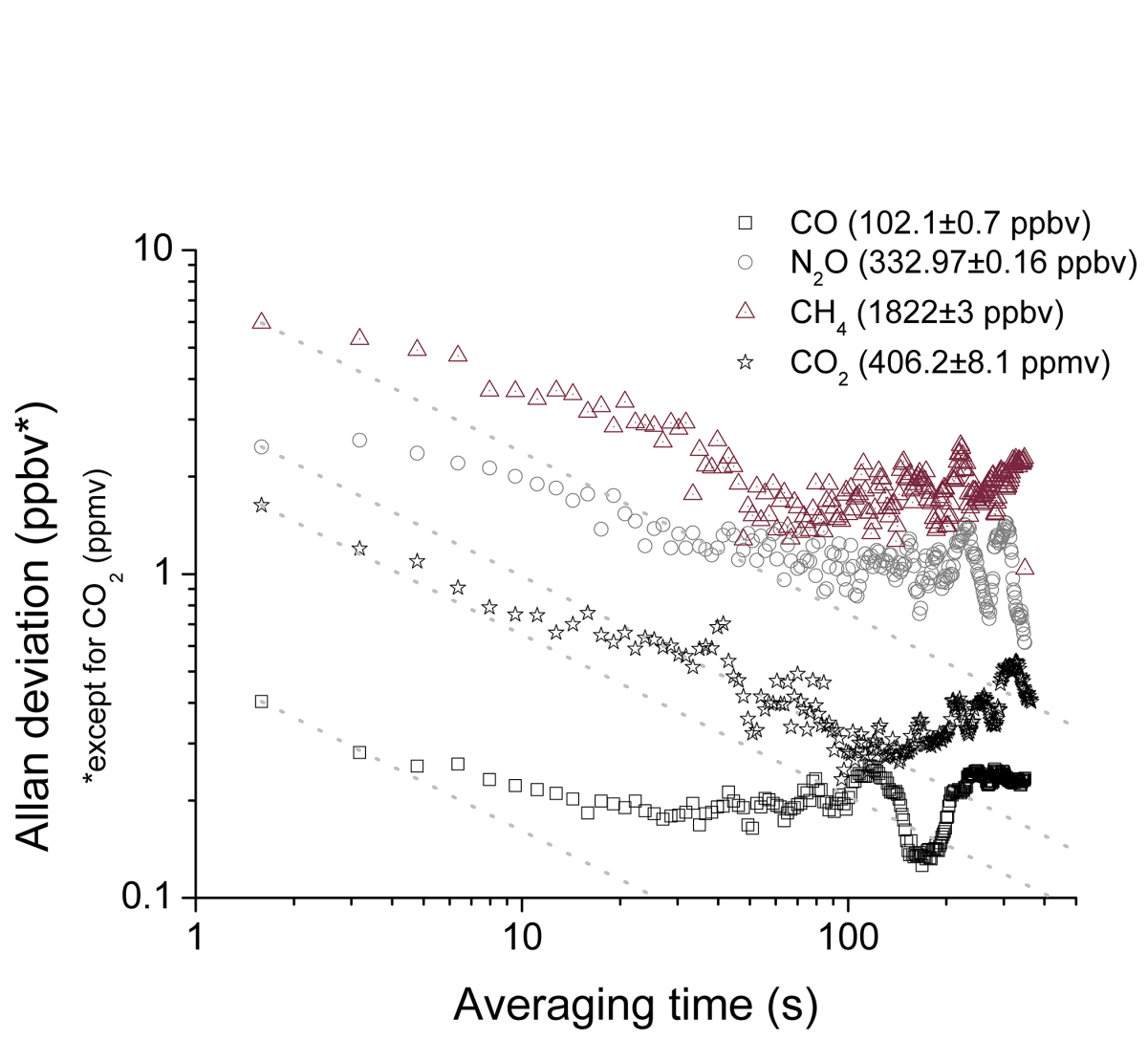

Figure 7. Allan deviation plots showing long term precision and drift behaviour. The expected Allan deviation for an ideal white noise is given as a comparison (dashed lines).

AMTD

8, 9165-9207, 2015

\section{An airborne infrared laser spectrometer for in-situ trace gas measurements}

V. Catoire et al.

Title Page

Abstract

Introduction

Conclusions

References

Tables

Figures

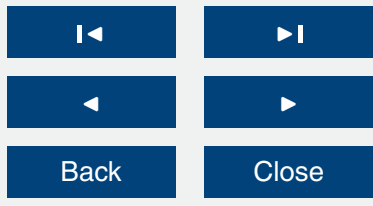

Full Screen / Esc

Printer-friendly Version

Interactive Discussion 


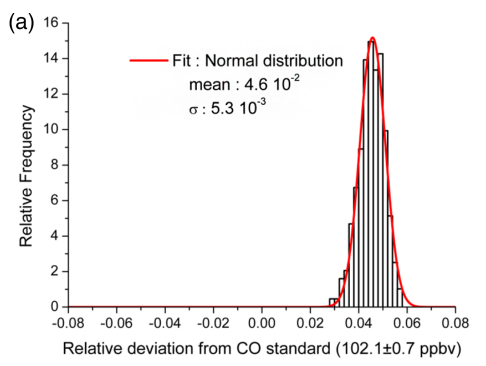

AMTD

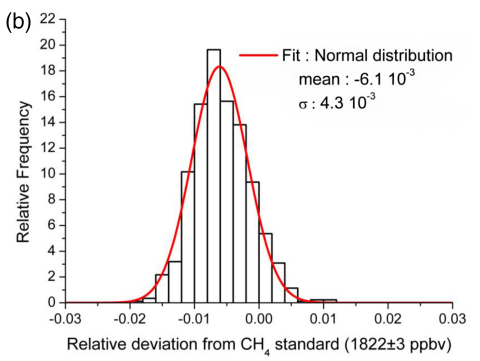

8, 9165-9207, 2015

\section{An airborne infrared laser spectrometer for in-situ trace gas measurements}

V. Catoire et al.

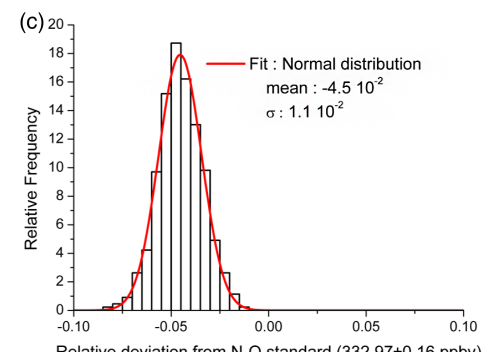

Title Page

Abstract

Introduction

Conclusions

References

Tables

Figures

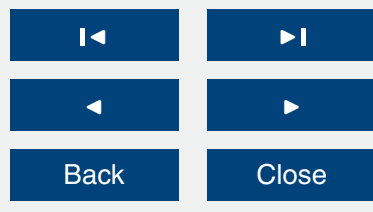

Full Screen / Esc

Figure 8. Histograms illustrating measurement dispersion for $\mathrm{CO}$ (a), $\mathrm{CH}_{4}$ (b) and $\mathrm{N}_{2} \mathrm{O}$ (c) relatively to standard gas concentrations. The mean values represent the measurement bias and $\sigma$ the standard deviation for the fitted distribution assumed to be normal (Gaussian). Relative frequencies are normalized to $100 \%$.

Printer-friendly Version

Interactive Discussion

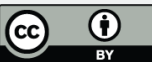



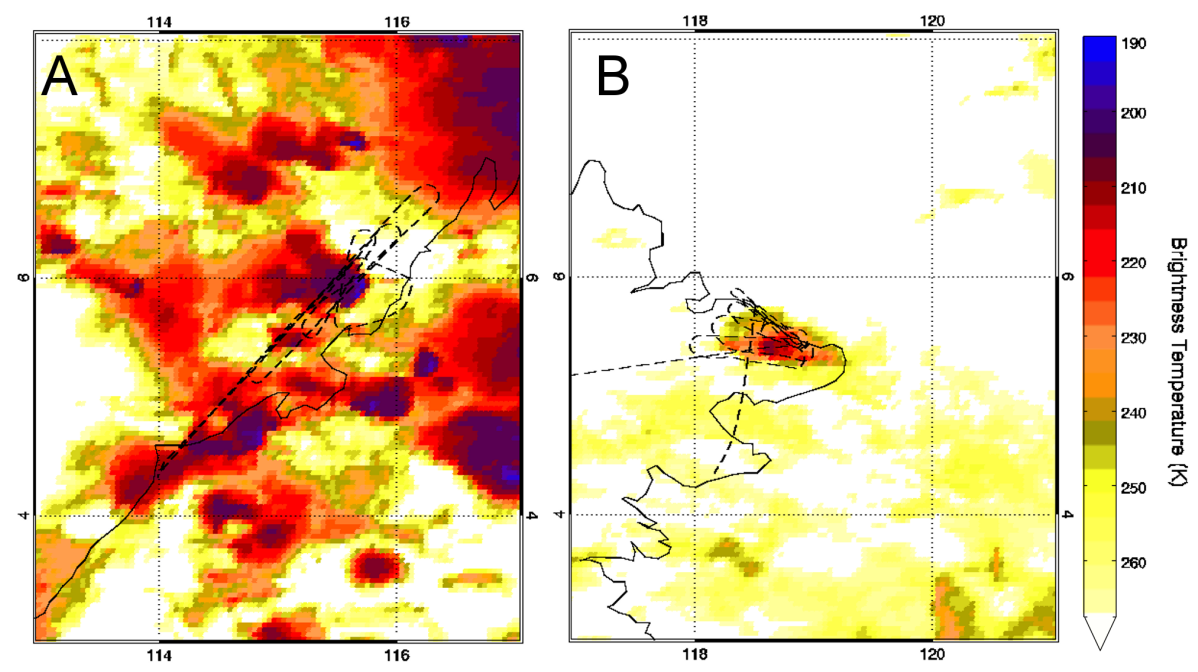

Figure 9. Brightness temperature from IR MTSAT-2 channel IR108 (10.3-11.3 $\mu \mathrm{m})$, obtained at 09:00 UTC on 19 November 2011 (a) and 10:00 UTC on 9 December 2011 (b). The flight tracks are represented in dashed lines.
AMTD

8, 9165-9207, 2015

An airborne infrared laser spectrometer for in-situ trace gas measurements

V. Catoire et al.

Title Page

Abstract

Introduction

Conclusions

References

Tables

Figures

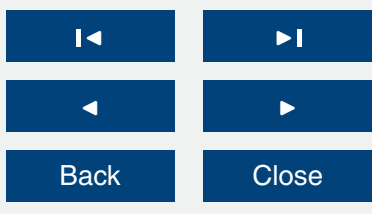

Full Screen / Esc

Printer-friendly Version

Interactive Discussion 

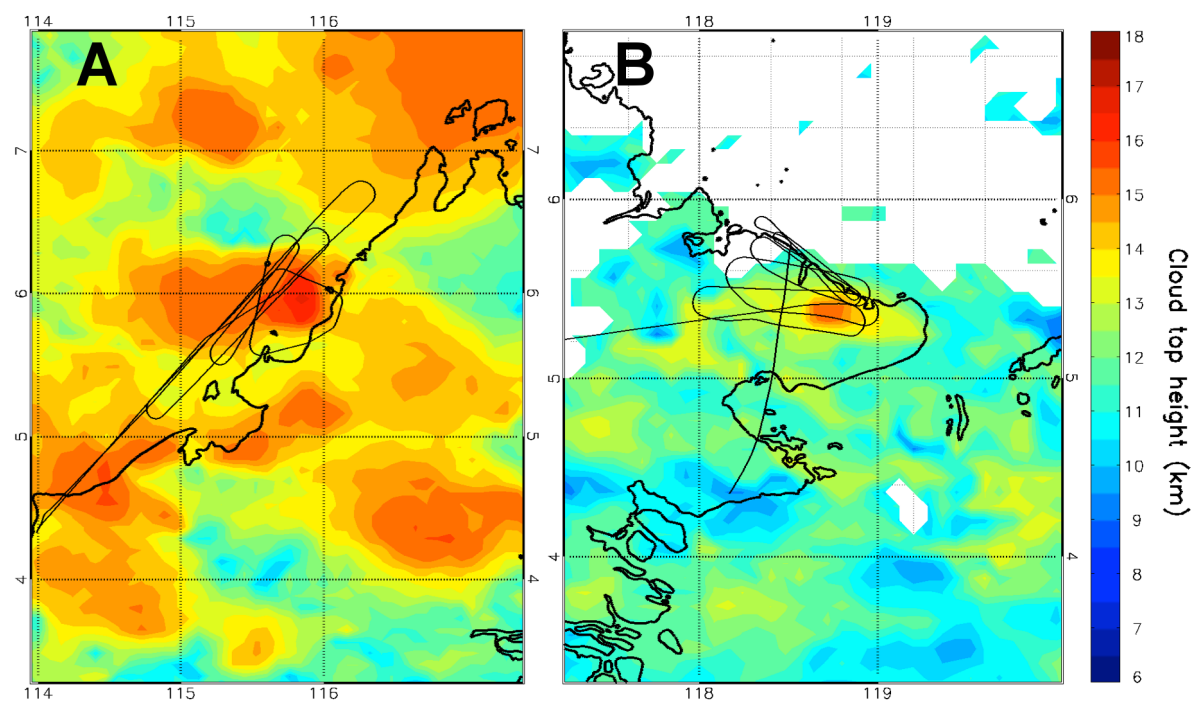

Figure 10. Top cloud height estimate by Hamada and Nishi (2010; available at http://database. rish.kyoto-u.ac.jp/arch/ctop/index_e.html) from the brightness temperature from MTSAT-2 (11$12 \mu \mathrm{m}$ ), obtained at 09:00 UTC on 19 November 2011 (a) and 10:00 UTC on 9 December 2011 (b). The flight tracks are represented in dark lines.

\section{AMTD}

8, 9165-9207, 2015

\section{An airborne infrared laser spectrometer for in-situ trace gas measurements}

V. Catoire et al.

\section{Title Page}

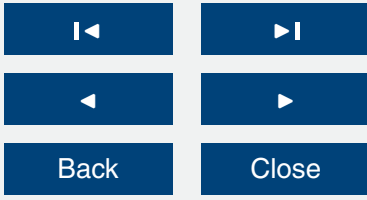

Full Screen / Esc

Printer-friendly Version

Interactive Discussion 


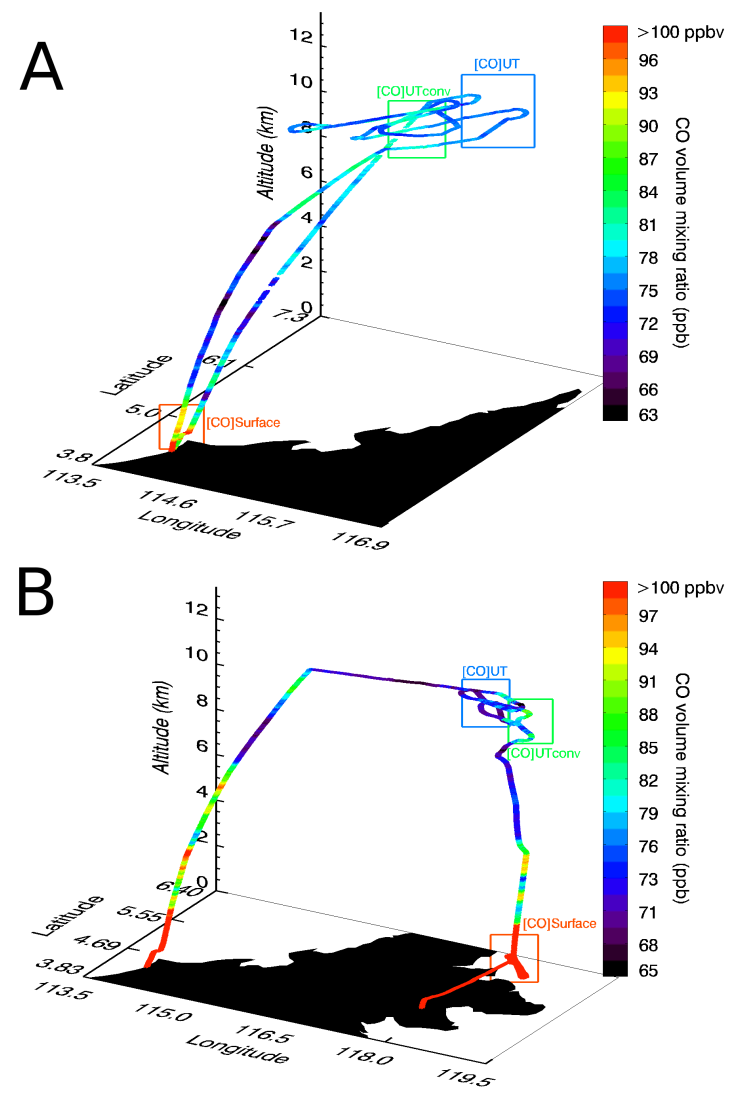

Figure 11. CO volume mixing ratio along the flight trajectories for the flights on 19 November 2011 (a) and on 9 December 2011 (b).

\section{AMTD}

\section{8, 9165-9207, 2015}

\section{An airborne infrared laser spectrometer for in-situ trace gas measurements}

V. Catoire et al.

\section{Title Page}

\section{Abstract}

Introduction

Conclusions

References

Tables

Figures

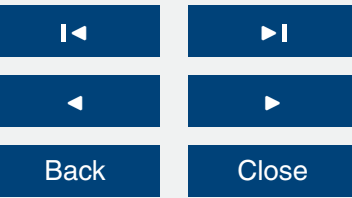

Full Screen / Esc

Printer-friendly Version

Interactive Discussion 


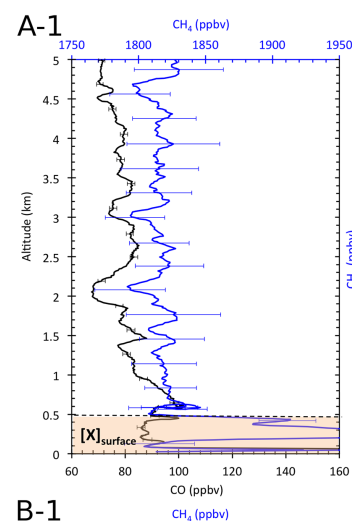

AMTD

8, 9165-9207, 2015

\section{An airborne infrared laser spectrometer for in-situ trace gas measurements}

V. Catoire et al.

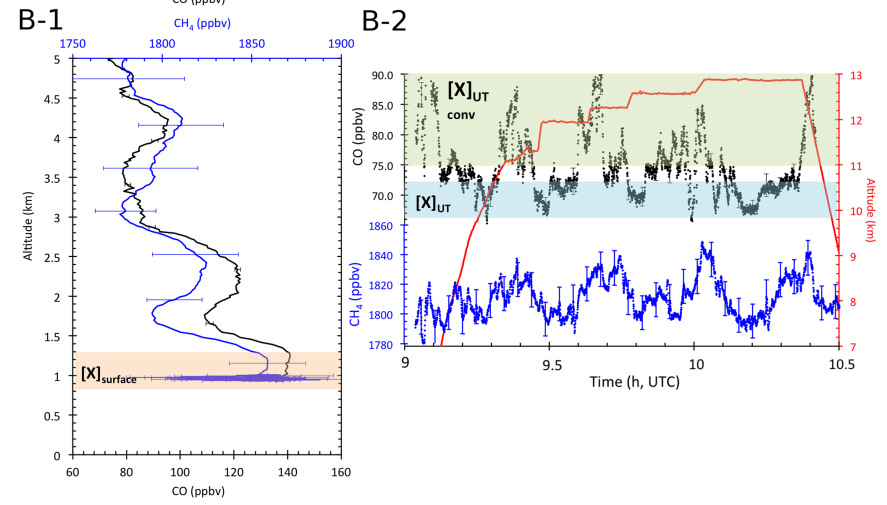

Title Page

Abstract

Introduction

Conclusions

References

Tables

Figures

14

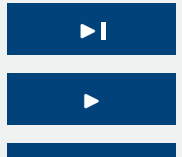

Back

Close

Figure 12. $\mathrm{CO}$ (in black) and $\mathrm{CH}_{4}$ (in blue) volume mixing ratio vs. altitude (a1, b1) and vs. time (a2, b2) for the flights on 19 November 2011 (a) and on 9 December 2011 (b). $[X]_{\text {surface }},[X]_{U T}$ and $[X]_{U T}$ conv represent the volume mixing ratios of $\mathrm{CO}$ or $\mathrm{CH}_{4}$ in the boundary layer, in the upper troposphere and in the upper troposphere influenced by the convection, respectively. The vertical profiles of vmr on 19 November and on 9 December are measured during the take-off and the landing of the aircraft and below the convection.

Printer-friendly Version

Interactive Discussion 